\title{
Phytotherapy and Women's Reproductive Health: The Cameroonian Perspective
}

Authors

Affiliations
Dieudonne Njamen ${ }^{1}$, Marie Alfrede Mvondo ${ }^{1,2}$, Sefirin Djiogue ${ }^{1}$, Germain Jean Magloire Ketcha Wanda ${ }^{3}$, Chantal Beatrice Magne Nde ${ }^{4}$, Günter Vollmer ${ }^{5}$

The affiliations are listed at the end of the article

\author{
Key words \\ - women reproductive health \\ - African pharmacopoeia \\ - emmenagogue \\ uterine flow suppressors \\ - anti-infertility \\ - abortifacient
}

\section{Abstract \\ $\nabla$}

Approximately $80 \%$ of the population in Africa use traditional medicinal plants to improve their state of health. The reason of such a wide use of medicinal plants has been mainly attributed to their accessibility and affordability. Expectation of little if any side effects, of a "natural" and therefore safe treatment regimen, as well as traditional beliefs additionally contribute to their popularity. Several of these plants are used by women to relieve problems related to their reproductive health, during or after their reproductive life, during pregnancy, or following parturition. The African pharmacopoeia thus provides plants used for preventing and/or treating gynecological infections, dysmenorrhea, irregular menstruations, oligomenorrhea or protracted menstruation, and infertility. Such plants may then be used as antimicrobians, emmenagogues, or as suppressors of uterine flow. African medicinal plants are also

\section{Introduction \\ $\nabla$}

Traditional societies in Africa and elsewhere have always used herbs to promote health [1]. According to Okoli et al. [2], traditional medical practices on the African continent date as far back as 4000 years and were the sole medical system for health care before the advent of conventional medicine. Even today, traditional medicine is still the predominant means of health care in developing countries where about $80 \%$ of their total population depends on it for their well-being [3]. The reason of such a broad use of medicinal plants has been mainly attributed to their accessibility and affordability. Expectation of little if any side effects, of a "natural" and therefore safe treatment regimen, as well as traditional beliefs addititionally contribute to their popularity [3]. used during pregnancy for prenatal care, against fetal malposition or malpresentation, retained dead fetus, and against threatened abortion. Some others are used as anti-fertilizing drugs for birth control. Such plants may exert various activities, namely, anti-implantation or early abortifacient, anti-zygotic, blastocytotoxic, and anti-ovulatory effects. Some herbs could also act as sexual drive suppressors or as a post-coital contraceptive by reducing the fertility index. A number of these plants have already been subject to scientific investigations and many of their properties have been assessed as estrogenic, oxytocic, or anti-implantation. Taking into account the diversity of the African pharmacopoeia, we are still at an early stage in the phytochemical and pharmacological characterization of these medicinal plants that affect the female reproductive system, in order to determine, through in vitro and in vivo studies, their pharmacological properties and their active principles.

In this traditional system of medicine, plant extracts in forms of concoctions or infusions are used to treat a wide range of diseases. Some of these plants are used in connection with female reproductive health. Throughout history, women have tried to control or enhance their fertility with various levels of societal support. Since then, plant drugs have been used for their effects on reproductive function particularly for suppressing fertility, regulating menstrual cyclicity, relieving dysmenorrhea, treating menopausal symptoms, and breast pain. Plant materials have also been used during pregnancy against fetal malposition, threatened abortion, or amnionitis affecting the newborn $[4,5]$. The sites of action of fertility and/ or antifertility agents in females comprise the hypothalamus, the anterior pituitary, the ovary, the oviduct, the uterus, and the vagina. Plants in question affect the reproductive system through 
Table 1 Some Cameroonian medicinal plants with estrogenic properties.

\begin{tabular}{|c|c|c|c|c|c|}
\hline Name & Family & $\begin{array}{l}\text { Plant part } \\
\text { used }\end{array}$ & Extract & Estrogenic effects & Authors \\
\hline Brenania brieyi & Rubiaceae & Fruits & Methanolic extract & $\begin{array}{l}\text { Stimulated uterine growth and vaginal epi- } \\
\text { thelial proliferation. }\end{array}$ & $\begin{array}{l}\text { Magne Ndé et al. } \\
{[12]}\end{array}$ \\
\hline \multirow[t]{2}{*}{ Erythrina lysistemon } & \multirow[t]{2}{*}{ Fabaceae } & \multirow[t]{2}{*}{ Stem barks } & \multirow[t]{2}{*}{ Ethyl acetate extract } & $\begin{array}{l}\text { Stimulated phosphatase alkaline in Ishikawa } \\
\text { cells; } \\
\text { slightly stimulated uterine growth. }\end{array}$ & Tanee et al. [10] \\
\hline & & & & $\begin{array}{l}\text { Prevented bone loss, increased HDL-choles- } \\
\text { terol and decreased triglycerides. }\end{array}$ & Njamen et al. [11] \\
\hline Millettia conraui & Leguminoseae & Stem barks & Ethyl acetate extract & \multirow{3}{*}{$\begin{array}{l}\text { Increased uterine and vaginal epithelial } \\
\text { heights; } \\
\text { stimulated alkaline phosphatase in Ishikawa } \\
\text { cells. }\end{array}$} & \multirow[t]{3}{*}{ Njamen et al. [13] } \\
\hline Millettia drastica & Leguminoseae & Stem barks & Ethyl acetate extract & & \\
\hline Bridellia ferruginea & Leguminoseae & Leaves & Methanolic extract & & \\
\hline Aloe buttneri & Liliaceae & Leaves & \multirow[t]{4}{*}{ Aqueous } & \multirow{4}{*}{$\begin{array}{l}\text { Stimulated uterine growth, increased } \\
\text { weight; } \\
\text { increased ovarian and uterine levels; } \\
\text { increased serum estradiol levels and } \\
\text { decreased ovarian cholesterol. }\end{array}$} & \multirow{4}{*}{$\begin{array}{l}\text { Telefo et al. [16, } \\
\text { 17] }\end{array}$} \\
\hline Dicliptera verticillata & Acantahceae & Leaves & & & \\
\hline Justicia insularis & Acanthaceae & Leaves & & & \\
\hline $\begin{array}{l}\text { Hibiscus } \\
\text { macranthus }\end{array}$ & Malvaceae & Stem leaves & & & \\
\hline Senecio biafrae & Asteraceae & Leaves & Aqueous & $\begin{array}{l}\text { Puberty onset and stimulation of folliculo- } \\
\text { genesis. }\end{array}$ & Lienou et al. [18] \\
\hline
\end{tabular}

estrogenic/anti-estrogenic, anti-inflammatory, analgesic, and antinociceptive activities. Plant extracts with estrogen-like properties in particular have been reported to mostly contain compounds endowed with estrogenic activities. Such compounds commonly known as phytoestrogens should be referred to as plant secondary metabolites with estrogenic activity, as they mimic part of estrogen action through estrogen receptor-mediated mechanisms. In addition, their mechanism of action depends on the levels of endogenous estrogens [6]. The present review aimed to highlight Central African medicinal plants used by women to relieve problems related to their reproductive health during or after their reproductive life, during pregnancy, or following parturition, with an emphasis on plants originating from Cameroon.

\section{Estrogen-like Acitivities of Secondary Metabolites from Some Central African Medicinal Plants $\nabla$}

As previously reported [7-9], xenobiotics with estrogenic properties and plant secondary metabolites with this activity in particular preferentially exert their biological activity by: (1) mimicking the action of endogenous estrogens; (2) acting as estrogen antagonists; (3) altering the pattern of synthesis and metabolism of endogenous hormones; and (4) modifying hormone receptor values.

Up to date, a large variety of studies have reported the estrogenic properties of a number of Central African medicinal plants, namely, Eryhtrina lysistemon (Fabaceae) [10,11], Brenania brieyi (Rubiaceae) [12], Millettia conraui (Leguminosae), Millettia drastica (Leguminosae), Bridelia ferruginea (Leguminosae) [13], and Erythrina poeppigiana (Fabaceae) [14,15]. A mixture of Aloe buttneri (Liliacae), Justicia insularis (Acanthaceae), Hibiscus macranthus (Malvaceae), and Dicliptera verticillata (Acanthaceae) has also been associated with estrogenic properties [16-18]. The body of evidence for the respective estrogenic properties and of the above-cited plants is summarized in $\bullet$ Table 1.

All the above-listed plant extracts exhibited direct estrogenic effects probably because of the presence of metabolites acting through either or both of the two estrogen receptors. To continue with the pharmacological characterization of these extracts, extended phytochemical studies are required. In-depth phytochemical studies have already been conducted on some of these plants.

As far as the Erythrina lysistemon extract is concerned, following a phytochemical analysis, alpinumisoflavone and abyssinone $\mathrm{V}$ 4'-methyl-ether have been isolated as major estrogenic constituents $[19,20]$. In the same study, alpinumisoflavone (an isoflavone) and abyssinone V-4'-methyl-ether (a flavanone) were found to be responsible for the estrogenic effects of the crude extract of Erythrina lysistemon, as they stimulated uterine growth and/or vaginal proliferation. This estrogenic activity was shown to be estrogen receptor-mediated as both compounds bound both subtypes of the estrogen receptor in a ligand binding assay, although not with the same affinity and preference. Furthermore, alpinumisoflavone and abyssinone $\mathrm{V}-4$ '-methyl-ether reduced atherogenic risks by decreasing the two assessed atherogenic parameters, namely, the total cholesterol/HDL-cholesterol ratio and the atherogenic index of plasma in ovariectomized Wistar rats serving as a preclinical model for postmenopausal conditions. In the same study, both compounds were found to decrease serum gonadotrophin levels and to reduce the hot flush activity by increasing the ratio of FSH on LH [19]. Finally, whereas alpinumisoflavone induced clear estrogenic effects both on classical and nonclassical estrogen targets, the flavanone abyssinone $\mathrm{V}-4$ 'methyl-ether did affect only the vagina (suggesting the safety of treatment with this compound towards the uterus of female rats) and nonclassical estrogen targets such as the lipid metabolism, implying a tissue specific effect.

Concerning the study on Erythrina poeppigiana, crude methanolic and dichloromethane extracts of the stem bark of this plant induced significant estrogenic effects on some classical estrogenic targets, namely the uterus and vagina, following a three-day uterotrophic assay with ovariectomized rats (unpublished observations). Using classic chromatographic methods, five new isoflavones derivatives, namely, 5,4'-dihydroxy-7-methoxy-3'-(3methylbuten-2-yl)isoflavone, 5,2',4'-trihydroxy-7-methoxy-5'(3-methylbuten-2-yl)isoflavone, 5,4'-dihydroxy-7-methoxy-3'- 
(3-methyl-2-hydroxybuten-3-yl)isoflavone, 3'-formyl-5,4'-dihydroxy-7-methoxyisoflavone, and 5-hydroxy-3"-hydroxy-2", 2"-dimethyldihydropyrano[5",6": 3',4']isoflavone, as well as six known compounds, wighteone, $3^{\prime}$-isoprenylgenistein, isolupabigenin, alpinumisoflavone, erypoegin $\mathrm{D}$, and crystacarpin, most of which are structurally related to the soy isoflavone genistein, were isolated [14]. Ligand binding assays with estrogen receptor- $\alpha$ and $-\beta$ revealed that isoprenyl and dimethylpyrano substituents in ring A reduced the affinity of binding to ER $\beta$ approximately 100-fold compared to genistein; the isoprenyl substituent in ring B was better accommodated, allowing 3'-isoprenylgenistein to bind with ca. 10-fold lower affinity than genistein [14]. As a follow-up study on this plant, the estrogenic properties of the isolated isoflavones derivatives with isoprenyl and/or 7-methoxy substitution were evaluated using estrogen receptor- $\alpha-$ and $-\beta$-dependent reporter gene assays. These compounds are particularly interesting as they represent naturally occurring structural modifications, namely, isoprenylation and/or methoxylation at various positions of the genistein skeleton. These modifications were associated with a statistically significant activation of the ER $\alpha$ - and ER $\beta$-dependent reporter gene expression starting from $0.1 \mathrm{nM}$ and resulting in distinct functional properties. For example, the 7-methoxy-3'-isoprenyl and the 7-methoxy-3'-(3-methyl-2-hydroxybuten-3-yl) derivatives induced an $E R \alpha$ - and $E R \beta$-coupled luciferase activity at a concentration ten times lower than that of genistein. Conversely, a double prenylation at positions 8 and $3^{\prime}$ was found to be associated with an almost complete loss of activity in the ER $\alpha$-dependent system; but in the ER $\beta$ expressing system, the effectiveness remained on a statistically significant level, demonstrating an "exclusive ER $\beta$ selectivity" in U2OS cells [15]. It will be interesting to investigate whether and to what extent these properties translate into in vivo effects, e.g., regarding bone and menopausal health.

Millettia griffoniana is used in traditional medicine in some village communities of Cameroon to treat menopausal disorders among others. Following phytochemistry, the estrogenic activities of some compounds isolated from M. griffoniana, namely, griffonianone $\mathrm{C}$, griffonianone $\mathrm{E}, 7-\mathrm{O}$-geranylformononetin, 4'$O$-geranylisoquiritigenin, $\quad 4^{\prime}$-methoxy-7-O-[(E)-3-methyl-7-hydroxymethyl-2,6-octadienyl]isoflavone, and 3',4'-dihydroxy-70 -[(E)-3,7-dimethyl-2,6-octadienyl]isoflavone, could be assessed [21]. Three different ER $\alpha$-dependent assays revealed weak estrogenic properties of the above-mentioned substances. Griffonianone $\mathrm{C}$ was selected for in-depth studies on the modulation of the expression of several estrogen-responsive genes in various organs of ovariectomized rats $[22,23]$, confirming mild estrogenic properties and excluding the risk of stimulation of uterine proliferation.

Additional research efforts focused on the following four Cameroonian medicinal plants, Aloe buttneri, Justicia insularis, Hibiscus macranthus, and Dicliptera verticillata. The leaves of these four medicinal plants were mixed in the proportions indicated in traditional medicine and tested for hormonal properties in immature female Wistar rats. This mixture has been shown to significantly increase the weight of the ovaries and uterus, as well as their total proteins levels, and the serum estradiol level at the dose of $94 \mathrm{mg} / \mathrm{kg} /$ day. These effects were accentuated in the pubertal period $[16,17]$, probably due to the increase of estrogen receptors expression during puberty. The same authors showed that the acqueous extract from leaves and stem bark of Senecio biafrae induced premature puberty onset in immature female Wistar rat after a 30-day period of treatment at the doses of 8 ,
32, and $64 \mathrm{mg} / \mathrm{kg} /$ day, respectively, indicated by an effective folliculogenesis [18].

An experimental endpoint not related to reproduction but to menopausal health is the bone. In this respect, from the Cameroonian medicinal plant Pterospermum acerifolium, two phytoceramides were isolated and shown to exhibit estrogenic activities assessed by alkaline phosphatase production in osteoblasts [24].

\section{Cameroonian Medicinal Herbs and Women's Reproductive Health}

$\nabla$

Women reproductive health does not only comprise fertility control or treatment of infertility problems but also implies genital organ health (prevention and/or treatment of gynecological infections). Many Cameroonian medicinal plants are therefore used as contraceptives (to prevent ovulation or fertilization), abortifacients (to prevent implantation or to push out unwanted conceptus), emmenagogues (to stimulate uterine flow), or oxytocics (to stimulate uterine contractions, particularly to promote labor) [25]. Some other plants are used for vaginal douching to prevent pregnancy or infections [26] or to enhance sexual stimulation of the male partner by drying or tightening the vagina $[27,28]$.

Besides the availability of the present methods of birth control, the population explosion and unintended pregnancies continue to pose major public health issues worldwide. The world population has exceeded $6.43 \times 10^{9}$ [29] and is increasing by $1 \times 10^{9}$ every 12 years. Ninety-five percent of this growth is in the developing nations, and particularly in Africa. In the USA, half of all pregnancies are unintended, which results in more than $1 \times 10^{6}$ elective abortions annually [30,31]. This calls for a better method of contraception that is acceptable, effective, and available both in the developed and developing nations. In the African pharmacopoeia, there are an appreciable number of plants endowed with antifertility properties. Antifertility is a term used for the prevention of pregnancy and is often referred to as birth control. The basic aim of antifertility drugs is to prevent conception or fertilization. Though considerable progress has been made for the development of highly effective, acceptable, and reversible methods of contraception among females, options on the male side are still slow and limited [32].

As far as females are concerned, antifertility drugs are those that control ovulation and, if regularly consumed, function as effective contraceptives. For instance, widely known steroidal oral contraceptives are chemicals that control the female menstrual cycle and ovulation.

Natural products traditionally used as remedies for birth control in women could exert various activities: anti-implantation or early abortifacient, anti-zygotic, blastocytotoxic, and anti-ovulation. Some herbs could act as sexual drive suppressors or as postcoital contraceptive by reducing the fertility index [32,33].

Birth control is not the sole burden of women as far as their reproductive health is concerned. Many women in Africa still face the problem of infertility. Indeed, infertility, defined as the inability to conceive after one year of regular intercourse, is said to affect $8-14 \%$ of couples in European and Eastern countries [34, 35]. In Africa, infertility is a serious reproductive health problem with regional prevalence rates of 30-40\% [36]. Infection, which is the most common cause of infertility, affects the physical health of both men and women. Women in particular, also commonly suffer from severe negative social consequences such as stigmatization, ostracism, abuse, and economic deprivation [37-39]. The 
effective management of infertility therefore has a considerable impact on reproductive health in Africa. Traditional medicinal herbs used to treat female infertility may thus act against urogenital infections, tubal blocage, anovulatory cycles, or premature menopause.

An emmenagogue is an herb which stimulates menstrual bleeding. To provoke menstrual bleedings, emmenagogue herbs may act by stimulating uterine contractions. In the case of pregnancy, emmenagogue herbs might provoke, according to the stage of the pregnancy, abortion or childbirth. These emmenagogue herbs can then be used either to treat amenorrhea, or as oxytocic to hasten labor, or as an abortifacient.

Some other plants are traditionally used against oligomenorrheae or protracted menstruation (menorrhagia). Plants may also help during pregnancy against fetal malposition, threatened abortion, or amnionitis affecting the new born.

In 1996, Adjanohoun et al. [40] catalogued a large number of Cameroonian traditional medicinal plants among which were those used for women's reproductive health. In $\odot$ Table 2, we summarized some of the Cameroonian medicinal plants used for women's reproductive purposes, as compiled from the Cameroonian Pharmacopoeia published by Adjanohoun et al. [40]. In this table, plants are classified according to their traditional use.

\section{Conclusion}

\section{$\nabla$}

The tropical forest continues to provide raw materials for the discovery of new medicinal products in view of the large diversity of its flora. In the African pharmacopoeia, many plants are used for women's reproductive health and particularly for fertility, genital organ health, or for birth control. In this paper, we have reviewed the knowledge on plants traditionally used for women's reproductive purposes mostly in central parts of Africa. A significant number of these plants are found in Cameroon. Among these traditional medicinal herbs, some have already been characterized scientifically, although to a varying degree, and several of their properties are attributed to estrogenic, oxytocic, or anti-implantatory properties. Taking into account the diversity of the Cameroonian pharmacopoeia, there is still a lot to do for the phytochemical and pharmacological characterization of these medicinal plants.

\section{Conflict of Interest \\ $\nabla$}

The authors declare no conflict of interest.

\footnotetext{
Affiliations

${ }^{1}$ Department of Animal Biology and Physiology, Faculty of Science, University of Yaounde 1, Yaounde, Cameroon

${ }^{2}$ Department of Animal Biology, Faculty of Science, University of Dschang, Dschang, Cameroon

${ }^{3}$ Department of Psychology, Faculty of Arts, Letters and Social Sciences, University of Yaounde 1, Yaounde, Cameroon

${ }^{4}$ Prince Henry's Institute for Medical Research, Melbourne, Australia

${ }^{5}$ Molecular Cell Physiology and Endocrinology, Institute of Zoology, University of Technology, Dresden, Germany
}

Table 2 Summary of Cameroonian medicinal plants and their traditional use for women's reproductive health (compiled from the Cameroon Pharmacopoeia, by Adjanohoun et al. [40]).

\begin{tabular}{|c|c|c|c|c|}
\hline Disorders & Botanical name & Vernacular name & Origin & Part used \\
\hline Amenorrhea & $\begin{array}{l}\text { Acanthospermum hispidum } \\
\text { (Asteraceae) }\end{array}$ & Guirlayi in Fufulde (Cameroon). & Widespread throughout tropical Africa. & Leafy shoot \\
\hline $\begin{array}{l}\text { Breast } \\
\text { abscess }\end{array}$ & $\begin{array}{l}\text { Cogniauxia podolaena Baill } \\
\text { (Cucurbitaceae) }\end{array}$ & $\begin{array}{l}\text { "Beyeme elok" in Bulu or "Kol ekona ezouo" } \\
\text { in Badjoun (Cameroon). }\end{array}$ & $\begin{array}{l}\text { Widespread in Cameroon, Gabon, Congo, and } \\
\text { Angola. }\end{array}$ & Leaves \\
\hline Cervicitis & $\begin{array}{l}\text { Desmodium hirtum (Legu- } \\
\text { minoseae-Papilionoideae) }\end{array}$ & “Sac-sac” in Mgem Mgem (Cameroon). & Found in savanna and pasture lands. & $\begin{array}{l}\text { Leaves and } \\
\text { stems }\end{array}$ \\
\hline \multirow[t]{2}{*}{$\begin{array}{l}\text { Defective } \\
\text { lactation }\end{array}$} & $\begin{array}{l}\text { Elephantopus mollis } \\
\text { (Asteraceae) }\end{array}$ & $\begin{array}{l}\text { "Akiba” in Bulu or “Toll” in Ewondo } \\
\text { (Cameroon). }\end{array}$ & $\begin{array}{l}\text { Found in abandoned cultivated land and in fringing } \\
\text { forest. }\end{array}$ & Stem bark \\
\hline & $\begin{array}{l}\text { Zanthoxylum gilletii De } \\
\text { Willd (Rutaceae) }\end{array}$ & "Bongo" in Ewondo (Cameroon). & $\begin{array}{l}\text { Forest regrowths, young secondary forests, from Si- } \\
\text { erra Leone to Angola and Sudan. }\end{array}$ & Barks \\
\hline \multirow[t]{8}{*}{$\begin{array}{l}\text { Dys- } \\
\text { menorrhea }\end{array}$} & $\begin{array}{l}\text { Acanthus montanus } \\
\text { (Acanthaceae) }\end{array}$ & $\begin{array}{l}\text { "Ndole elok" in Ewondo or "Ngick" in Bassa } \\
\text { (Cameroon). }\end{array}$ & Forest region plants occurring from Benin to Angola. & $\begin{array}{l}\text { Whole } \\
\text { plant }\end{array}$ \\
\hline & $\begin{array}{l}\text { Aloe buettneri } \\
\text { (Liliaceae) }\end{array}$ & $\begin{array}{l}\text { "Kagbayi” in Bamoun, “Lah-Ndih" in Bana, } \\
\text { "Gassa" in Bandjoun, or “Adjan nkom” in } \\
\text { Eton (Cameroon). }\end{array}$ & $\begin{array}{l}\text { Savanna species, growing preferably in rocky areas. } \\
\text { Found from Mali to the Central African Republic, } \\
\text { Congo, and Angola to Malawi. }\end{array}$ & Leaves \\
\hline & Aloe vera (Liliaceae) & $\begin{array}{l}\text { "Kouovut” or “Nschahsoure” in Bamoun } \\
\text { (Cameroon). }\end{array}$ & $\begin{array}{l}\text { Probably native of the Mediterranean region; } \\
\text { propagated by rhizome. }\end{array}$ & Leaves \\
\hline & $\begin{array}{l}\text { Anonidium mannii } \\
\text { (Annonaceae) }\end{array}$ & “Mombou kombo" in Kaka. & $\begin{array}{l}\text { A species of forest undergrowth. It is also found in } \\
\text { Ghana, Nigeria, and Democratic Republic of Congo. }\end{array}$ & Bark \\
\hline & $\begin{array}{l}\text { Begonia schaeferi } \\
\text { (Begoniaceae) }\end{array}$ & "Woyamowo" in Bana (Cameroon). & Found in forests, by streams. & Leaves \\
\hline & $\begin{array}{l}\text { Centella asiatica } \\
\text { (Apiaceae) }\end{array}$ & “longion diep” in Bamenda (Cameroon). & $\begin{array}{l}\text { Widely distributed in tropical Africa, Asia, and Aus- } \\
\text { tralia. West Africa-East Africa. }\end{array}$ & $\begin{array}{l}\text { Stem and } \\
\text { leaves }\end{array}$ \\
\hline & $\begin{array}{l}\text { Cissus quadrangularis } \\
\text { (Vitaceae) }\end{array}$ & $\begin{array}{l}\text { "Coeur" in Bafut, "Ndieh gap" in Bamoun, } \\
\text { "Thor-Ngehkue" in Bana, "Nkohsat” in } \\
\text { Bagangte, or "Nyo" or "Njel" in Bassa } \\
\text { (Cameroon). }\end{array}$ & $\begin{array}{l}\text { Widespread in the drier parts of Africa, Arabia, and } \\
\text { India. }\end{array}$ & Fresh stem \\
\hline & $\begin{array}{l}\text { Clerodendrum volubile } \\
\text { (Verbenaceae) }\end{array}$ & “Tughlen” in Babungo (Cameroon). & $\begin{array}{l}\text { Secondary forests, gallery forests, and along } \\
\text { streams. }\end{array}$ & Bark \\
\hline
\end{tabular}


Table 2 Continued

\begin{tabular}{|c|c|c|c|c|}
\hline Disorders & Botanical name & Vernacular name & Origin & Part used \\
\hline \multirow[t]{15}{*}{$\begin{array}{l}\text { Dysmenor- } \\
\text { rhea }\end{array}$} & $\begin{array}{l}\text { Emilia coccinea } \\
\text { (Asteraceae) }\end{array}$ & $\begin{array}{l}\text { "Alonvu” in Bulu, "Thohi” in Fufulde, or } \\
\text { "Mahomambio" in Bassa (Cameroon). }\end{array}$ & $\begin{array}{l}\text { Frequently found on roadsides, in sunny parts of the } \\
\text { forest, and in the Guineo-Sudanese savanna. }\end{array}$ & $\begin{array}{l}\text { Fresh } \\
\text { leaves }\end{array}$ \\
\hline & $\begin{array}{l}\text { Entandrophragma cylin- } \\
\text { dricum (Meliaceae) }\end{array}$ & $\begin{array}{l}\text { "Sbicha" in Banyangi, or "Assie" in Ewondo } \\
\text { (Cameroon). }\end{array}$ & Species common in Guinean forest. & Bark \\
\hline & $\begin{array}{l}\text { Gardenia aqualla } \\
\text { (Rubiaceae) }\end{array}$ & “Digale” in Fufulde (Cameroon). & $\begin{array}{l}\text { Hills in West Africa, in Ubangi-Shari, Sudan, and } \\
\text { Kenya. }\end{array}$ & Roots \\
\hline & $\begin{array}{l}\text { Gouania longipetala } \\
\text { (Rhamnaceae) }\end{array}$ & $\begin{array}{l}\text { "Konteh" in Lamso or "Sobomissile" in } \\
\text { Badjoue (Cameroon). }\end{array}$ & Frequent in forest regrowth and in forest margins. & $\begin{array}{l}\text { Fresh } \\
\text { leaves }\end{array}$ \\
\hline & $\begin{array}{l}\text { Khaya senegalensis } \\
\text { (Meliaceae) }\end{array}$ & “Dalehi” or “Kalei” in Fufulde (Cameroon). & $\begin{array}{l}\text { Sudano-Zambezian and sahelian region species, } \\
\text { widespread from Senegal to Uganda. }\end{array}$ & Bark \\
\hline & $\begin{array}{l}\text { Morinda lucida } \\
\text { (Rubiaceae) }\end{array}$ & "Akeng" in Ewondo (Cameroon). & $\begin{array}{l}\text { Forest region species, widespread from Guinea to } \\
\text { Congo. It is more abundant in secondary formations. }\end{array}$ & Bark \\
\hline & $\begin{array}{l}\text { Ozoroa pulcherrima } \\
\text { (Anacardiaceae) }\end{array}$ & “Korewinabae” in Fufulde (Cameroon). & $\begin{array}{l}\text { Sudano-Zambezian species, widespread from } \\
\text { Guinea to Cameroon, in Central African Republic, in } \\
\text { Ethiopia, and in the Sudan. }\end{array}$ & Roots \\
\hline & $\begin{array}{l}\text { Picralima nitida } \\
\text { (Apocynaceae) }\end{array}$ & “Bamborutuk” in Maka (Cameroon). & $\begin{array}{l}\text { Species occurring in African forest regions, spread } \\
\text { through Côte d'Ivoire to Democratic Republic of } \\
\text { Congo and Uganda. }\end{array}$ & Fruits \\
\hline & $\begin{array}{l}\text { Piper umbellatum } \\
\text { (Piperaceae) }\end{array}$ & $\begin{array}{l}\text { "Mbubua" in Bana, “Mbebueh" in Badjoun, } \\
\text { "Aboo Medjan" in Ewondo or "Abomejang" } \\
\text { in Bulu, "Mbobou” in Balesing or "Bobong } \\
\text { ngoh" in Kaka (Cameroon). }\end{array}$ & $\begin{array}{l}\text { Heliophile species, widespread from Guinea to } \\
\text { Cameroon and Angola. }\end{array}$ & $\begin{array}{l}\text { Whole } \\
\text { plant }\end{array}$ \\
\hline & $\begin{array}{l}\text { Polyalthia suaveolens } \\
\text { (Annonaceae) }\end{array}$ & “Afoumengen” in Mankon (Cameroon). & $\begin{array}{l}\text { Primary forest, beside the river from Sierra Leone to } \\
\text { Ghana. }\end{array}$ & Bark \\
\hline & $\begin{array}{l}\text { Rauvolfia vomitoria } \\
\text { (Apocynaceae) }\end{array}$ & $\begin{array}{l}\text { "Medzanga medzanga" in Ewondo, } \\
\text { "Ikwadongdongui" in Bassa, or "Sebal" in } \\
\text { Fufulde (Cameroon). }\end{array}$ & $\begin{array}{l}\text { Guinea-Congolese species, widespread in secondary } \\
\text { formations; it grows in fringing forests and small } \\
\text { groves of the Sudano-Guinean region. }\end{array}$ & Root bark \\
\hline & $\begin{array}{l}\text { Sansevieria trifasciata } \\
\text { (Agavaceae) }\end{array}$ & $\begin{array}{l}\text { "Lah-Njue" in Bana or "Bascori" in Fufulde } \\
\text { (Cameroon). }\end{array}$ & $\begin{array}{l}\text { Usually found around dwellings from Sierra Leone to } \\
\text { Democratic Republic of Congo. }\end{array}$ & Leaves \\
\hline & $\begin{array}{l}\text { Setaria megaphylla } \\
\text { (Poaceae) }\end{array}$ & $\begin{array}{l}\text { "Akwo kwo" in Bakossi, “Kiwawa” in Lamso, } \\
\text { or "Dikok” in Bakundu (Cameroon). }\end{array}$ & $\begin{array}{l}\text { Species very common in forest zones; marshy places } \\
\text { in forest, widespread in tropical and southern Africa } \\
\text { and tropical America. }\end{array}$ & Leaves \\
\hline & $\begin{array}{l}\text { Tylophora cameroonica } \\
\text { (Asclepiadaceae) }\end{array}$ & $\begin{array}{l}\text { "Babambe", "Babambi”, or "Zarawolhi” in } \\
\text { Fufulde (Cameroon). }\end{array}$ & $\begin{array}{l}\text { Paleotropical plant; widespread through inter-tropi- } \\
\text { cal Africa mostly in dry regions. }\end{array}$ & Leaves \\
\hline & $\begin{array}{l}\text { Zehneria scabra } \\
\text { (Cucurbitaceae) }\end{array}$ & $\begin{array}{l}\text { "Njombe" or "Kwandalempa" in Maka, } \\
\text { "Bohgwei” in Lamso (Cameroon). }\end{array}$ & $\begin{array}{l}\text { Savanna, rocky and ruderal plains. Equatorial Africa } \\
\text { from Nigeria to Angola. }\end{array}$ & Roots \\
\hline \multirow[t]{7}{*}{$\begin{array}{l}\text { Irregular } \\
\text { menstrua- } \\
\text { tion }\end{array}$} & Basella alba (Basellaceae) & $\begin{array}{l}\text { "Ndore" in Bafut, "Laire gapou” in Fufulde, } \\
\text { "Kefuveyit" in Oku, "Nnab" in Metta, or } \\
\text { "Loh" in Bagangte (Cameroon). }\end{array}$ & $\begin{array}{l}\text { West Africa to Asia, West Indies and East Africa; } \\
\text { cultivated in vegetable gardens. }\end{array}$ & Aerial parts \\
\hline & $\begin{array}{l}\text { Clerodendrum umbellatum } \\
\text { (Verbenaceae) }\end{array}$ & $\begin{array}{l}\text { "Nganwi" in Bafut, "Binyem" or "Dion” in } \\
\text { Bassa, "Elok dibi" in Ewondo, or "Dor nkol" } \\
\text { in Kaka (Cameroon). }\end{array}$ & Roadsides, swampy places. & Leaves \\
\hline & $\begin{array}{l}\text { Eremomastax speciosa } \\
\text { (Acanthaceae) }\end{array}$ & $\begin{array}{l}\text { "Banguimoh" in Bafut, "Ekunte" in Bakossi, } \\
\text { "Mejama Njombe" or "Maijai ma njombe" } \\
\text { in Bakweri, "Essan dja" in Yebekolo, "Noni" } \\
\text { in Mbo, or "Purple leaf" in Pidgin (Came- } \\
\text { roon). }\end{array}$ & Widespread in tropical Africa. & $\begin{array}{l}\text { Fresh } \\
\text { leaves }\end{array}$ \\
\hline & $\begin{array}{l}\text { Harungana madagas- } \\
\text { cariensis (Hypericaceae) }\end{array}$ & $\begin{array}{l}\text { "Toune" in Bamoun, “Ntone” in Bayang, or } \\
\text { "Tiotinton" in Esso (Cameroon). }\end{array}$ & $\begin{array}{l}\text { Sun-loving secondary forest species widely spread } \\
\text { in all intertropical Africa, Madagascar, and Mas- } \\
\text { careigne islands. }\end{array}$ & Roots \\
\hline & $\begin{array}{l}\text { Khaya senegalensis } \\
\text { (Meliaceae) }\end{array}$ & “Dalehi” or “Kalei” in Fufulde (Cameroon). & $\begin{array}{l}\text { Sudano-Zambezian and sahelian region species, } \\
\text { widespread from Senegal to Uganda. }\end{array}$ & Stem bark \\
\hline & $\begin{array}{l}\text { Milicia excelsa } \\
\text { (Moraceae) }\end{array}$ & $\begin{array}{l}\text { "Abang" in Ewondo, "Abang Iroko" in Mvele } \\
\text { "Chou-lak" in Bagangte, "Mmat" in Bayang } \\
\text { (Cameroon). }\end{array}$ & $\begin{array}{l}\text { Plant growing in dense forests and forest galleries as } \\
\text { well as savanna regions. Found from Côte d'Ivoire to } \\
\text { Cameroon, Gabon to Democratic Republic of Con- } \\
\text { go, Mozambique, and Angola. }\end{array}$ & Bark \\
\hline & $\begin{array}{l}\text { Vernonia conferta } \\
\text { (Asteraceae) }\end{array}$ & “Mbet mbu” in Bagante (Cameroon). & $\begin{array}{l}\text { Secondary forest from Cameroon through Central } \\
\text { Africa to Uganda and Angola. }\end{array}$ & Bark \\
\hline \multirow{3}{*}{$\begin{array}{l}\text { Menorrha- } \\
\text { gia/pro- } \\
\text { tracted } \\
\text { menstrua- } \\
\text { tion }\end{array}$} & $\begin{array}{l}\text { Amaranthus hybridus } \\
\text { (Amaranthaceae) }\end{array}$ & “Majouohe” in Balessing (Cameroon). & Commonly found cultivated or as a weed. & Leaves \\
\hline & $\begin{array}{l}\text { Ampelocissus penthaphylla } \\
\text { (Vitaceae) }\end{array}$ & “Nkweeti” in Lamso (Cameroon). & $\begin{array}{l}\text { Abundant in wooded savanna extending from } \\
\text { Senegal to Mozambique. }\end{array}$ & Leaves \\
\hline & $\begin{array}{l}\text { Aspilia africana } \\
\text { (Asteraceae) }\end{array}$ & $\begin{array}{l}\text { "Kigavir" or “Kighair” in Lamso (Came- } \\
\text { roon). }\end{array}$ & $\begin{array}{l}\text { Secondary formation species, occurring from } \\
\text { Senegal to Cameroon. }\end{array}$ & Leaves \\
\hline
\end{tabular}


Table 2 Continued

\begin{tabular}{|c|c|c|c|c|}
\hline Disorders & Botanical name & Vernacular name & Origin & Part used \\
\hline \multirow{5}{*}{$\begin{array}{l}\text { Menorrha- } \\
\text { gia/pro- } \\
\text { tracted } \\
\text { menstrua- } \\
\text { tion }\end{array}$} & $\begin{array}{l}\text { Dyschoriste perrottetii } \\
\text { (Acanthaceae) }\end{array}$ & “Nse net" in Lamso (Cameroon). & $\begin{array}{l}\text { Plant found in tropical Africa from Senegal to Angola } \\
\text { and from Ethiopia to South Africa. }\end{array}$ & Leaves \\
\hline & $\begin{array}{l}\text { Prunus africana } \\
\text { (Rosaceae) }\end{array}$ & $\begin{array}{l}\text { "Bakiva" in Banyangi or "Kepa", "Kira", } \\
\text { "Kilum", and "Win wan" in Lamso (Came- } \\
\text { roon). }\end{array}$ & Widely distributed on the mountains. & Leaves \\
\hline & $\begin{array}{l}\text { Senecio biafrae } \\
\text { (Asteraceae) }\end{array}$ & $\begin{array}{l}\text { "Nsob" in Bakossi, "Nduwane" in Bana, or } \\
\text { "Nboh" or "Borh nja nkom" in Lamso } \\
\text { (Cameroon). }\end{array}$ & Cocoa plantation, fallows, roadsides. & Leafy twig \\
\hline & $\begin{array}{l}\text { Sonchus angustissimus } \\
\text { (Asteraceae) }\end{array}$ & $\begin{array}{l}\text { "Bankar", "Kirah", or “Mborvingua" in } \\
\text { Lamso (Cameroon). }\end{array}$ & High savanna. & $\begin{array}{l}\text { Stem and } \\
\text { leaves }\end{array}$ \\
\hline & $\begin{array}{l}\text { Spilanthes africana } \\
\text { (Asteraceae) }\end{array}$ & $\begin{array}{l}\text { "Ntossi" in Badjoue or "Shishur sheshiv" in } \\
\text { Lamso (Cameroon). }\end{array}$ & $\begin{array}{l}\text { A plant of wet lands. It is found in countries of West } \\
\text { and Central Africa. }\end{array}$ & Leaves \\
\hline $\begin{array}{l}\text { Oligo- } \\
\text { menorrhea }\end{array}$ & $\begin{array}{l}\text { Asystasia gangetica } \\
\text { (Acanthaceae) }\end{array}$ & “Basu ebu” in Ejagham (Cameroon). & Widespread throughout the tropics. & $\begin{array}{l}\text { Soft aerial } \\
\text { parts }\end{array}$ \\
\hline $\begin{array}{l}\text { Uterine } \\
\text { hemorrhage }\end{array}$ & $\begin{array}{l}\text { Setaria megaphylla } \\
\text { (Poaceae) }\end{array}$ & $\begin{array}{l}\text { "Akwo kwo" in Bakossi, "Dikoko” in Bakun- } \\
\text { du, "Kiwawa” in Lamso, or “Mekoapkoap” } \\
\text { in Vomvom (Cameroon). }\end{array}$ & $\begin{array}{l}\text { Species very common in forest zones; marshy places } \\
\text { in forests, widespread in tropical and southern Africa } \\
\text { and tropical America. }\end{array}$ & $\begin{array}{l}\text { Leaves and } \\
\text { stems }\end{array}$ \\
\hline Vaginitis & $\begin{array}{l}\text { Cissus quadrangularis } \\
\text { (Vitaceae) }\end{array}$ & $\begin{array}{l}\text { "Coeur" in Bafut, "Ndieh gap" in Bamoun, } \\
\text { "Thor-Ngehkue" in Bana, "Nkohsat" in } \\
\text { Bagangte, or "Nyo" or "Njel" in Bassa } \\
\text { (Cameroon). }\end{array}$ & $\begin{array}{l}\text { Widespread in the drier parts of Africa, Arabia, and } \\
\text { India. }\end{array}$ & Leafy twig \\
\hline \multirow[t]{4}{*}{$\begin{array}{l}\text { Vulvo- } \\
\text { vaginitis }\end{array}$} & $\begin{array}{l}\text { Capsicum frutescens } \\
\text { (Solanaceae) }\end{array}$ & $\begin{array}{l}\text { "Olene" in Badjoue, "Hehoy" in Banen, } \\
\text { "Ondondo ndodo" in Bulu, "Ndondon" in } \\
\text { Ewondo, or "Shishur Shengamri" in Lamso } \\
\text { (Cameroon). }\end{array}$ & $\begin{array}{l}\text { Pantropical species growing in secondary forma- } \\
\text { tions, in the field, and sometimes cultivated. }\end{array}$ & $\begin{array}{l}\text { Aerial parts } \\
\text { and fuits }\end{array}$ \\
\hline & $\begin{array}{l}\text { Clerodendrum umbellatum } \\
\text { (Verbenaceae) }\end{array}$ & $\begin{array}{l}\text { "Nganwi" in Bafut, "Binyem" in Bassa, Elok } \\
\text { dibi" in Ewondo (Cameroon) }\end{array}$ & Roadsides, swampy places. & $\begin{array}{l}\text { Tops of the } \\
\text { plant }\end{array}$ \\
\hline & $\begin{array}{l}\text { Detarium microcarpum } \\
\text { (Leguminoseae-Caesalpi- } \\
\text { noideae) }\end{array}$ & “Nkwazi” in Bakoko (Cameroon). & $\begin{array}{l}\text { Woodland species, widespread in all the Sudano- } \\
\text { Zambesian region of Africa. }\end{array}$ & Bark \\
\hline & $\begin{array}{l}\text { Dichrocephala integrifolia } \\
\text { (Asteraceae) }\end{array}$ & $\begin{array}{l}\text { "Chemambor" in Bafut, "Yieri" in Bamoun, } \\
\text { "Tchitchiani” in Fefea, "Abiabi" in Bikom, } \\
\text { "Esosombuog" in Bakossi, or "Tape" in } \\
\text { Fufulde (Cameroon). }\end{array}$ & A weed of high ground. & $\begin{array}{l}\text { Tops of the } \\
\text { plant }\end{array}$ \\
\hline \multirow[t]{2}{*}{$\begin{array}{l}\text { Imperforate } \\
\text { vagina }\end{array}$} & $\begin{array}{l}\text { Euphorbia hirta } \\
\text { (Euphorbiaceae) }\end{array}$ & $\begin{array}{l}\text { "Ndo" in Babungo, "Pengmey" in Bafaji, } \\
\text { Mpemeu" in Bamoun, "Tenkwuvue" in } \\
\text { Bana, Ewuda manyongo" in Douala, "Okoul } \\
\text { bifes" in Ewondo, or "Endemhi” in Fufulde } \\
\text { (Cameroon). }\end{array}$ & $\begin{array}{l}\text { Wild species, growing in various areas, along roads } \\
\text { particularly on waste grounds and in old cultivations; } \\
\text { pantropical. }\end{array}$ & Leaves \\
\hline & $\begin{array}{l}\text { Hilleria latifolia } \\
\text { (Phytolacaceae) }\end{array}$ & $\begin{array}{l}\text { "Akange" in Bafut, "Essumba" in Kaka } \\
\text { (Cameroon). }\end{array}$ & $\begin{array}{l}\text { Common in forest stations, banana plantations, } \\
\text { palm groves, and outskirts of villages. }\end{array}$ & Roots \\
\hline \multirow[t]{6}{*}{ Leucorrhea } & $\begin{array}{l}\text { Ageratum conyzoides } \\
\text { (Asteraceae) }\end{array}$ & $\begin{array}{l}\text { "Eshing" in Akono, "Mobangtu" in Bali, } \\
\text { "Mejottefu" in Bamoun, "Ogaate" or "Ok- } \\
\text { pati" in Bulu, "Nyat elok" or "Okpati" in } \\
\text { Ewondo, and “Nde das se" in Sanaga } \\
\text { (Cameroon). }\end{array}$ & Widespread in Africa. & Leaves \\
\hline & $\begin{array}{l}\text { Alchornea cordifolia } \\
\text { (Euphorbiaceae) }\end{array}$ & $\begin{array}{l}\text { "Enzezam aboe" in Bulu, "Diboybonji" in } \\
\text { Douala, "Aboe" in Ewondo, "Mbienchie" in } \\
\text { Bafang, or Bambemi" in Hausa (Came- } \\
\text { roon). }\end{array}$ & Widespread in tropical Africa. & Leaves \\
\hline & $\begin{array}{l}\text { Commelina thomasii } \\
\text { (Commelinaceae) }\end{array}$ & “Gougouot” in Bamoun (Cameroon). & $\begin{array}{l}\text { Secondary lowland rain forest, persisting in farms } \\
\text { and plantations. }\end{array}$ & Leaves \\
\hline & $\begin{array}{l}\text { Dichrocephala integrifolia } \\
\text { (Asteraceae) }\end{array}$ & $\begin{array}{l}\text { "Chemambor" in Bafut, "Yieri” in Bamoun, } \\
\text { "Tchitchiani” in Fefea, "Abiabi” in Bikom, } \\
\text { "Esosombuog" in Bakossi, or “Tape” in } \\
\text { Fufulde (Cameroon). }\end{array}$ & A weed of high ground. & $\begin{array}{l}\text { Tops of the } \\
\text { plant }\end{array}$ \\
\hline & $\begin{array}{l}\text { Hibiscus sabdariffa } \\
\text { (Malvaceae) }\end{array}$ & $\begin{array}{l}\text { "Mejue” in Bakossi, “Fouchi” in Bamoun, } \\
\text { "Ewouda maya” in Douala, "Okro’o" in } \\
\text { Kwen, or “Essan" in Mvele (Cameroon). }\end{array}$ & Widely cultivated in the tropics. & Leafy twig \\
\hline & $\begin{array}{l}\text { Spanthodea campanulata } \\
\text { (Bignoniaceae) }\end{array}$ & $\begin{array}{l}\text { "Vivet" in Bamoun, "Kilulone" in Lamso, } \\
\text { "Evovone" in Bulu, "Fowara" in Kwen, or } \\
\text { Bolabola" in Vomvom (Cameroon). }\end{array}$ & Mainly fringing forests. & Leaves \\
\hline
\end{tabular}


Table 2 Continued

\begin{tabular}{|c|c|c|c|c|}
\hline Disorders & Botanical name & Vernacular name & Origin & Part used \\
\hline \multirow{20}{*}{$\begin{array}{l}\text { Infertility } \\
\text { (primary and } \\
\text { secondary) }\end{array}$} & $\begin{array}{l}\text { Asystasia deciplens } \\
\text { (Acanthaceae) }\end{array}$ & $\begin{array}{l}\text { "Nzuae” in Bakossi and “Mborfen” in Lamso } \\
\text { (Cameroon). }\end{array}$ & Swampy rain forest areas. & $\begin{array}{l}\text { Tops of the } \\
\text { plant }\end{array}$ \\
\hline & $\begin{array}{l}\text { Asystasia macrophylla } \\
\text { (Acanthaceae) }\end{array}$ & “Telofe" in Kaka (Cameroon). & $\begin{array}{l}\text { Found in Cameroon, Nigeria, Gabon, and Equatorial } \\
\text { Guinea. }\end{array}$ & Leaves \\
\hline & Hibiscus asper (Malvaceae) & “Ejimuwae” in Bakossi (Cameroon). & $\begin{array}{l}\text { A savanna species which is widespread in all } \\
\text { intertropical Africa. }\end{array}$ & $\begin{array}{l}\text { Whole } \\
\text { plant }\end{array}$ \\
\hline & $\begin{array}{l}\text { Hibiscus vitifolius } \\
\text { (Malvaceae) }\end{array}$ & “Kiwuoy" in Lamso (Cameroon). & Widespread in tropical Africa. & $\begin{array}{l}\text { Tops of the } \\
\text { plant }\end{array}$ \\
\hline & $\begin{array}{l}\text { Ipomoea mauritiana } \\
\text { (Convolvulaceae) }\end{array}$ & $\begin{array}{l}\text { "Ndongo Yagisse" in Yambassa (Cam- } \\
\text { eroon). }\end{array}$ & $\begin{array}{l}\text { Pantropical species, common in various plant for- } \\
\text { mations in sub-Saharan Africa. }\end{array}$ & Tuber \\
\hline & $\begin{array}{l}\text { Klainedoxa gabonensis } \\
\text { (Irvingiaceae) }\end{array}$ & “Boukoko” in Banka (Cameroon). & Found in forests. & Stem bark \\
\hline & $\begin{array}{l}\text { Lasianthera africana } \\
\text { (Icacinaceae) }\end{array}$ & “Badjimbo" in Bassa (Cameroon). & Found in secondary forests. & $\begin{array}{l}\text { Fresh } \\
\text { leaves }\end{array}$ \\
\hline & $\begin{array}{l}\text { Laportea aestuans } \\
\text { (Urticaceae) }\end{array}$ & $\begin{array}{l}\text { "Nduru likund" in Bassa, "Karara" in Hausa, } \\
\text { and "Kimbin" in Oku. }\end{array}$ & $\begin{array}{l}\text { Pantropical plant, widespread in humid regions. } \\
\text { Found in wastelands and on farms. }\end{array}$ & $\begin{array}{l}\text { Whole } \\
\text { plant }\end{array}$ \\
\hline & $\begin{array}{l}\text { Momordica charantia } \\
\text { (Cucurbitaceae) }\end{array}$ & $\begin{array}{l}\text { "Nzec-Zeneng" in Bbesi, “Njii Ngoue” in } \\
\text { Bamenda, or "Bohghwei" in Lamso } \\
\text { (Cameroon). }\end{array}$ & $\begin{array}{l}\text { Pantropical species growing especially in abandoned } \\
\text { cultivations. }\end{array}$ & Leafy twig \\
\hline & $\begin{array}{l}\text { Myrrianthus arboreus } \\
\text { (Moraceae) }\end{array}$ & $\begin{array}{l}\text { "Sanpute” in Bounde or “Loco’o” in Kaka } \\
\text { (Cameroon). }\end{array}$ & $\begin{array}{l}\text { Species frequent enough in primitive or secondary } \\
\text { forests, fringing forests, or clearings of Guineo-Con- } \\
\text { golese dense forest area. }\end{array}$ & $\begin{array}{l}\text { Fresh } \\
\text { leaves }\end{array}$ \\
\hline & $\begin{array}{l}\text { Pennisetum purpureum } \\
\text { (Poaceae) }\end{array}$ & $\begin{array}{l}\text { "Nto obwet" in Bamoun, "Sinsung" in Bana, } \\
\text { "Lekop" in Bassa, and "Kikhiai" or "Mjee" in } \\
\text { Lamso (Cameroon). }\end{array}$ & $\begin{array}{l}\text { Forest zone species, spread in Africa, now intro- } \\
\text { duced in other tropical regions. }\end{array}$ & Leaves \\
\hline & Pistia stratiotes (Araceae) & "Lah-chie" in Bana (Cameroon). & $\begin{array}{l}\text { Pantropical aquatic floating species growing } \\
\text { through intertropical Africa. }\end{array}$ & Leaves \\
\hline & $\begin{array}{l}\text { Premna quadrifolia } \\
\text { (Verbenaceae, Boragina- } \\
\text { ceae) }\end{array}$ & $\begin{array}{l}\text { "Mua-Ndong-dong” in Bakossi and “Nfesai” } \\
\text { in Lamso (Cameroon). }\end{array}$ & $\begin{array}{l}\text { Guinea-Congolese species which is found in } \\
\text { secondary formations. Widespread from Guinea to } \\
\text { Cameroon. }\end{array}$ & Leafy twig \\
\hline & $\begin{array}{l}\text { Raphidophora africana } \\
\text { (Araceae) }\end{array}$ & “Wonya” in Banka (Cameroon). & $\begin{array}{l}\text { A plant found along the west and central coast land } \\
\text { of Africa. }\end{array}$ & Leaves \\
\hline & $\begin{array}{l}\text { Ricinus communis } \\
\text { (Euphorbiaceae) }\end{array}$ & $\begin{array}{l}\text { "Mejang” or "Mijang” in Bamoun, “Lamdji” } \\
\text { in Bana, and "Shinjang” in Lamso (Came- } \\
\text { roon). }\end{array}$ & $\begin{array}{l}\text { Introduced species, widely cultivated in tropical } \\
\text { countries, now pantropical. }\end{array}$ & $\begin{array}{l}\text { Castor oil } \\
\text { extracted } \\
\text { from } \\
\text { Ricinus } \\
\text { communis } \\
\text { seeds }\end{array}$ \\
\hline & $\begin{array}{l}\text { Sida acuta } \\
\text { (Malvaceae) }\end{array}$ & $\begin{array}{l}\text { "Chubepa" in Bateh, "Zeyssim" in Bulu, and } \\
\text { "Saldori” or "Calori” in Fufulde (Cameroon). }\end{array}$ & $\begin{array}{l}\text { Pantropical wild species, growing of roadsides and in } \\
\text { wastelands. }\end{array}$ & Leaves \\
\hline & $\begin{array}{l}\text { Solanum torvum } \\
\text { (Solanaceae) }\end{array}$ & $\begin{array}{l}\text { "Elam-tam” or “Ngaleni sumembre” in Ba- } \\
\text { kossi and “Ngunmbia” in Kaka (Cameroon). }\end{array}$ & A very common weed throughout the tropics. & Fruits \\
\hline & $\begin{array}{l}\text { Trichilia gilgiana } \\
\text { (Meliaceae) }\end{array}$ & “Tuba” in Banka (Cameroon). & $\begin{array}{l}\text { Species frequent in the wetter types of lowland rain } \\
\text { forest. Extends from South Nigeria to Democratic } \\
\text { Republic of Congo, and Cabinda. }\end{array}$ & Bark \\
\hline & $\begin{array}{l}\text { Terminalia superba } \\
\text { (Combretaceae) }\end{array}$ & $\begin{array}{l}\text { "Nkwombo", "Nkwonda", or "Nkwondo" } \\
\text { in Bamoun, "Nguie" in Bamungo and } \\
\text { "Akom" in Bulu (Cameroon). }\end{array}$ & $\begin{array}{l}\text { Dense humid forest species, widespread from } \\
\text { Guinea to Democratic Republic of Congo. }\end{array}$ & Stem bark \\
\hline & $\begin{array}{l}\text { Zenheria scabra } \\
\text { (Cucurbitaceae) }\end{array}$ & $\begin{array}{l}\text { "Kwandalempa" or “Njombe” in Maka and } \\
\text { "Bohgwei” in Lamso (Cameroon). }\end{array}$ & $\begin{array}{l}\text { Savanna, rocky and ruderal plains. Equatorial Africa } \\
\text { from Nigeria to Angola. }\end{array}$ & Roots \\
\hline \multirow{5}{*}{$\begin{array}{l}\text { Pelvic } \\
\text { abscess/ } \\
\text { pelvic in- } \\
\text { flammatory } \\
\text { disease }\end{array}$} & $\begin{array}{l}\text { Acacia polyacantha (Legu- } \\
\text { minoseae-Mimosoideae) }\end{array}$ & “Ngombo" in Ewondo (Cameroon). & $\begin{array}{l}\text { Species growing in humid regions, from Senegal to } \\
\text { Nigeria as well as in eastern and southern Africa. }\end{array}$ & Stem bark \\
\hline & $\begin{array}{l}\text { Cogniauxia podolaena } \\
\text { (Cucurbitaceae) }\end{array}$ & $\begin{array}{l}\text { "Kol eona ezouo" in Badjoun, “Fui Gbain” in } \\
\text { Bali, "Kon-afu” in Banwa, and “Beyeme } \\
\text { elok” in Bulu (Cameroon). }\end{array}$ & $\begin{array}{l}\text { Species widespread in Gabon, in Cameroon, and in } \\
\text { Congo, found also in Angola. }\end{array}$ & Roots \\
\hline & $\begin{array}{l}\text { Drymaria cordata } \\
\text { (Caryophylaceae) }\end{array}$ & $\begin{array}{l}\text { "Chkerre" in Bakossi, "Mgou-minque" in } \\
\text { Bana, "Ntoh" in Banwa, "Hissona'si” in Bas- } \\
\text { sa, and “Oyang" or "Oyanga" in Ewondo } \\
\text { (Cameroon). }\end{array}$ & Widely dispersed in the tropics and subtropics. & $\begin{array}{l}\text { Whole } \\
\text { plant }\end{array}$ \\
\hline & $\begin{array}{l}\text { Hibiscus sabdariffa } \\
\text { (Malvaceae) }\end{array}$ & $\begin{array}{l}\text { “Mejue" in Bakossi, “Fouchi” in Bamoun, } \\
\text { "Ewouda maya” in Douala, “Okro'o" in } \\
\text { Kwen, and "Essan” in Mvele (Cameroon). }\end{array}$ & Widely cultivated in the tropics. & Aerial parts \\
\hline & $\begin{array}{l}\text { Leea guineensis } \\
\text { (Leeaceae) }\end{array}$ & “Totonn” in Bassa (Cameroon). & $\begin{array}{l}\text { Plant growing in humid places; found in the forest } \\
\text { region galleries throughout tropical Africa. }\end{array}$ & Leaves \\
\hline
\end{tabular}


Table 2 Continued

\begin{tabular}{|c|c|c|c|c|}
\hline Disorders & Botanical name & Vernacular name & Origin & Part used \\
\hline \multirow{2}{*}{$\begin{array}{l}\text { Pelvic } \\
\text { abscess/ } \\
\text { pelvic in- } \\
\text { flammatory } \\
\text { disease }\end{array}$} & $\begin{array}{l}\text { Mammea africana } \\
\text { (Clusiaceae) }\end{array}$ & $\begin{array}{l}\text { "Houng abodzog" in Bassa and "Abot zok" } \\
\text { or "Houng abodzog" in Ewondo (Came- } \\
\text { roon). }\end{array}$ & $\begin{array}{l}\text { Species found in the forest. Distributed from Sierra } \\
\text { Leone to Uganda and Angola. }\end{array}$ & Stem bark \\
\hline & $\begin{array}{l}\text { Piptadeniastrum africanum } \\
\text { (Leguminoseae-Mimosoi- } \\
\text { deae) }\end{array}$ & $\begin{array}{l}\text { "Atui" in Beti and Fang, "Tombou" in Kaka, } \\
\text { and "Mpie" in Maka (Cameroon). }\end{array}$ & $\begin{array}{l}\text { Tree found in dense, humid forests. Found in } \\
\text { Cameroon, Sierra Leone, Angola, and Uganda. }\end{array}$ & Stem bark \\
\hline $\begin{array}{l}\text { Premature } \\
\text { menopause }\end{array}$ & $\begin{array}{l}\text { Hemizygia welwitschii } \\
\text { (Lamiaceae) }\end{array}$ & "Sokri" in Gnem gnem. & Growing in clumps in dry stony grassland. & Leaves \\
\hline \multirow[t]{4}{*}{$\begin{array}{l}\text { Tubal } \\
\text { blockage }\end{array}$} & Eleusine indica (Poaceae) & $\begin{array}{l}\text { "Lisingesinge" in Bakweri, "Ngongui" in } \\
\text { Bassa and Douala (Cameroon). }\end{array}$ & $\begin{array}{l}\text { Species spread in all tropical regions; widespread in } \\
\text { all regions of tropical Africa. }\end{array}$ & Leaves \\
\hline & $\begin{array}{l}\text { Icacina tricantha } \\
\text { (Icacinaceae) }\end{array}$ & $\begin{array}{l}\text { "Koul issi" or “Moudici” in Bassa, and “Byem } \\
\text { elok" in Bulu (Cameroon). }\end{array}$ & $\begin{array}{l}\text { Undergrowth species of the forest region, usually } \\
\text { growing in secondary formations. }\end{array}$ & $\begin{array}{l}\text { Root } \\
\text { tubers }\end{array}$ \\
\hline & $\begin{array}{l}\text { Phyllanthus muellerianus } \\
\text { (Euphorbiaceae) }\end{array}$ & "Riribo" in Fufulde (Cameroon). & Forest species widespread in all intertropical Africa. & $\begin{array}{l}\text { Roots or } \\
\text { leaves }\end{array}$ \\
\hline & $\begin{array}{l}\text { Solanum aculeastrum } \\
\text { (Solanaceae) }\end{array}$ & $\begin{array}{l}\text { "Sircerka” in Bana, and “Kijah", "Kilum”, or } \\
\text { "Kira” in Lamso (Cameroon). }\end{array}$ & Found in Cameroon, tropical East Africa, and Angola. & Fruits \\
\hline \multirow[t]{18}{*}{$\begin{array}{l}\text { Urinary tract } \\
\text { infection }\end{array}$} & $\begin{array}{l}\text { Afromomum melegueta } \\
\text { (Zingiberaceae) }\end{array}$ & $\begin{array}{l}\text { "Koge" or “Mbong" in Bakossi, “Nbongo" in } \\
\text { Bassa or "Ndong” in Ewondo, and "Soc } \\
\text { kwa" in Bagante (Cameroon). }\end{array}$ & $\begin{array}{l}\text { Forest region plant, common in all intertropical } \\
\text { Africa, often cultivated. }\end{array}$ & $\begin{array}{l}\text { Grains and } \\
\text { rhizome }\end{array}$ \\
\hline & $\begin{array}{l}\text { Alchornea laxiflora } \\
\text { (Euphorbiaceae) }\end{array}$ & $\begin{array}{l}\text { "Eholo" in Bakossi and "Josos" in Bakweri } \\
\text { (Cameroon). }\end{array}$ & $\begin{array}{l}\text { Widespread in central, eastern, and southern } \\
\text { tropical Africa. }\end{array}$ & Leaves \\
\hline & $\begin{array}{l}\text { Asystasia macrophylla } \\
\text { (Acanthaceae) }\end{array}$ & "Telofe" in Kaka (Cameroon). & $\begin{array}{l}\text { Found in Cameroon, Nigeria, Gabon, Equatorial } \\
\text { Guinea. }\end{array}$ & Leaves \\
\hline & $\begin{array}{l}\text { Calotropis procera } \\
\text { (Asclepiadaceae) }\end{array}$ & "Bambambi" in Fufulde (Cameroon). & $\begin{array}{l}\text { Paleotropical plant, widespread through intertropi- } \\
\text { cal African mostly in dry regions. }\end{array}$ & Roots \\
\hline & $\begin{array}{l}\text { Cissus quadrangularis } \\
\text { (Vitaceae) }\end{array}$ & $\begin{array}{l}\text { "Coeur" in Bafut, "Ndieh gap" in Bamoun, } \\
\text { "Thor-Ngehkue" in Bana, "Nkohsat" in } \\
\text { Bagangte, or "Nyo" or "Njel" in Bassa } \\
\text { (Cameroon). }\end{array}$ & $\begin{array}{l}\text { Widespread in the drier parts of Africa, Arabia, and } \\
\text { India. }\end{array}$ & Stem \\
\hline & $\begin{array}{l}\text { Combretom hispidum } \\
\text { (Combretaceae) }\end{array}$ & “Amiomlo" in Badjoue (Cameroon). & $\begin{array}{l}\text { Fallows, semideciduous forests, clearings in the } \\
\text { evergreen forests, widespread from Guinea to } \\
\text { Angola. }\end{array}$ & Leaf \\
\hline & $\begin{array}{l}\text { Commelina congesta } \\
\text { (Commelinaceae) }\end{array}$ & "Nkoleke" in Bakossi (Cameroon). & Found in forests, sometimes in open. & Leaves \\
\hline & $\begin{array}{l}\text { Desmodium adscendens } \\
\text { (Leguminoseae-Papilionoi- } \\
\text { deae) }\end{array}$ & $\begin{array}{l}\text { "Pepeur" in Bakossi, "Owondo bekone" in } \\
\text { Bulu (Cameroon). }\end{array}$ & $\begin{array}{l}\text { Species widespread in Guinea, Cameroon, } \\
\text { extending to Zimbabwe. It exists in tropical America. } \\
\text { In Gabon, it is found in the forest regions and the } \\
\text { edges of the savanna. }\end{array}$ & Leaves \\
\hline & $\begin{array}{l}\text { Enantia chlorantha } \\
\text { (Annonaceae) }\end{array}$ & $\begin{array}{l}\text { "Menjap" in Banyagi, "Mfo'o" in Bulu, } \\
\text { "Upon" in Ewondo, and “Mpolo'o" in } \\
\text { Sanaga (Cameroon). }\end{array}$ & $\begin{array}{l}\text { Dense humid forest plant, spread through Nigeria } \\
\text { into Gabon. }\end{array}$ & Stem bark \\
\hline & $\begin{array}{l}\text { Eremomastax speciosa } \\
\text { (Acanthaceae) }\end{array}$ & $\begin{array}{l}\text { "Tankebi” in Mbo, "Purple leaf" in Pidgin, } \\
\text { "Essan dja" in Yebekolo, and “Ekunte” in } \\
\text { Bakossi (Cameroon). }\end{array}$ & Widespread in tropical Africa. & Leaves \\
\hline & $\begin{array}{l}\text { Euphorbia laterifolia } \\
\text { (Euphorbiaceae) }\end{array}$ & "Lahmbeuh" in Bagangte (Cameroon). & $\begin{array}{l}\text { Species usually planted as hedges. It grows from Si- } \\
\text { erra Leone to Cameroon. }\end{array}$ & $\begin{array}{l}\text { Whole } \\
\text { plant }\end{array}$ \\
\hline & $\begin{array}{l}\text { Khaya senegalensis } \\
\text { (Meliaceae) }\end{array}$ & "Dalehi" or "Kahi" in Fufulde (Cameroon). & $\begin{array}{l}\text { Sudano-Zambezian and sahelian region species, } \\
\text { widespread from Senegal to Uganda. }\end{array}$ & Stem bark \\
\hline & $\begin{array}{l}\text { Lapotera ovalifolia } \\
\text { (Urticaceae) }\end{array}$ & $\begin{array}{l}\text { "Anelembu" or "Talambo dop" in Bakossi, } \\
\text { "Kilikion" in Bassa, and "Sogo" in Emankon } \\
\text { (Cameroon). }\end{array}$ & Widespread, abundant on sandy and clay soils. & $\begin{array}{l}\text { Leaves and } \\
\text { bark }\end{array}$ \\
\hline & $\begin{array}{l}\text { Mondia whitei } \\
\text { (Periplocaceae) }\end{array}$ & $\begin{array}{l}\text { "Djiri”, “Katagora”, or “Eleli” in Fufulde } \\
\text { (Cameroon). }\end{array}$ & $\begin{array}{l}\text { Widely distributed in tropical Africa, from Guinea } \\
\text { through Cameroon to East Africa. }\end{array}$ & Roots \\
\hline & $\begin{array}{l}\text { Raphidiocystis mannii } \\
\text { (Cucurbitaceae) }\end{array}$ & "Nduh" in Bakossi (Cameroon). & Cameroon. & Leaves \\
\hline & $\begin{array}{l}\text { Spilanthes filicaulis } \\
\text { (Asteraceae) }\end{array}$ & $\begin{array}{l}\text { "Ehe ngui” in Bamenji, "Gniguep” in } \\
\text { Bamena, "Odongdong-si” in Ewondo, } \\
\text { "Leuk ngeub" in Bagangte, and “Ondodosi” } \\
\text { in Bulu (Cameroon). }\end{array}$ & $\begin{array}{l}\text { Plant growing in humid places, along the roads and } \\
\text { near dwelling houses. It is found in all the forest re- } \\
\text { gions of Africa. }\end{array}$ & Leaves \\
\hline & $\begin{array}{l}\text { Tragia benthami } \\
\text { (Euphorbiaceae) }\end{array}$ & $\begin{array}{l}\text { "Tulebuo" in Bakossi, "Mbepaa" in Bana, } \\
\text { and "Sas" in Ewondo (Cameroon). }\end{array}$ & $\begin{array}{l}\text { Secondary bushes in Cameroon, Sudan, Uganda, } \\
\text { Democratic Republic of Congo, and Angola. }\end{array}$ & $\begin{array}{l}\text { Leaves and } \\
\text { roots }\end{array}$ \\
\hline & $\begin{array}{l}\text { Zehneria scabra } \\
\text { (Cucurbitaceae) }\end{array}$ & $\begin{array}{l}\text { "Njombe" in Maka and "Bohgwei" in Lamso } \\
\text { (Cameroon). }\end{array}$ & $\begin{array}{l}\text { Savanna, rocky and ruderal plains. Equatorial Africa } \\
\text { from Nigeria to Angola. }\end{array}$ & Roots \\
\hline
\end{tabular}


Table 2 Continued

\begin{tabular}{|c|c|c|c|c|}
\hline Disorders & Botanical name & Vernacular name & Origin & Part used \\
\hline \multirow[t]{8}{*}{$\begin{array}{l}\text { Amnionitis } \\
\text { affecting the } \\
\text { newborn }\end{array}$} & $\begin{array}{l}\text { Ageratum conyzoides } \\
\text { (Asteraceae) }\end{array}$ & $\begin{array}{l}\text { "Eshing" in Akono, "Mobangtu" in Bali, } \\
\text { "Mejottefu" in Bamoun, "Ogaate" or "Ok- } \\
\text { pati" in Bulu, "Nyat elok" or "Okpati" in } \\
\text { Ewondo, and "Nde das se" in Sanaga } \\
\text { (Cameroon). }\end{array}$ & Widespread in Africa. & $\begin{array}{l}\text { Whole } \\
\text { plant }\end{array}$ \\
\hline & $\begin{array}{l}\text { Cleome rutidosperma } \\
\text { (Capparaceae) }\end{array}$ & $\begin{array}{l}\text { "Amborrenja" in Bafut, "Macomagniaga" in } \\
\text { Bassa, "Mephomonze" in Bouda, and } \\
\text { "Mbango" in Douala (Cameroon). }\end{array}$ & Species growing in all of tropical Africa. & $\begin{array}{l}\text { Whole } \\
\text { plant }\end{array}$ \\
\hline & $\begin{array}{l}\text { Commelina benghalensis } \\
\text { (Commelinaceae) }\end{array}$ & $\begin{array}{l}\text { "Nkwa" in Bafut, "Ngungwet" in Bamoun, } \\
\text { and "Kaalep" in Bassa (Cameroon). }\end{array}$ & $\begin{array}{l}\text { A weedy plant of open cultivated and wasted } \\
\text { ground, also in savanna. }\end{array}$ & $\begin{array}{l}\text { Whole } \\
\text { plant }\end{array}$ \\
\hline & Eleusine indica (Poaceae) & $\begin{array}{l}\text { "Lisingesinge" in Bakweri, "Ngongui" in } \\
\text { Bassa, and "Ngongui” in Douala (Cam- } \\
\text { eroon). }\end{array}$ & $\begin{array}{l}\text { Species spread in all tropical regions; widespread in } \\
\text { all regions of tropical Africa. }\end{array}$ & $\begin{array}{l}\text { Flowering } \\
\text { plant }\end{array}$ \\
\hline & $\begin{array}{l}\text { Euphorbia hirta } \\
\text { (Euphorbiaceae) }\end{array}$ & $\begin{array}{l}\text { "Okoul bifes" in Ewondo, "Mpemeu” in } \\
\text { Bamoun, "Ewuda manyongo" in Douala, } \\
\text { and "Endemhi” in Fufulde (Cameroon). }\end{array}$ & $\begin{array}{l}\text { Wild species, growing in various areas, along roads } \\
\text { particularly on waste grounds and in old cultivation. }\end{array}$ & $\begin{array}{l}\text { Whole } \\
\text { plant }\end{array}$ \\
\hline & $\begin{array}{l}\text { Portulaca oleracea } \\
\text { (Portulacaceae) }\end{array}$ & $\begin{array}{l}\text { "Kepingoup" or "Koupugoup” in Bamoun, } \\
\text { "Derdegue” in Mvele, and “Nyukutu nyu- } \\
\text { kutu" in Douala (Cameroon). }\end{array}$ & Cosmopolitan and ruderal species. & $\begin{array}{l}\text { Whole } \\
\text { plant }\end{array}$ \\
\hline & $\begin{array}{l}\text { Triplotaxis stellulifera } \\
\text { (Asteraceae) }\end{array}$ & $\begin{array}{l}\text { "Mudike musadi" in Douala, "Ntsam } \\
\text { ntsam" in Ewondo, and “Jogue” in Maka } \\
\text { (Cameroon). }\end{array}$ & $\begin{array}{l}\text { Weed widespread in the clearings of forest regions } \\
\text { from Liberia to Gabon and in Uganda. }\end{array}$ & $\begin{array}{l}\text { Whole } \\
\text { plant }\end{array}$ \\
\hline & $\begin{array}{l}\text { Gossypium barbadense } \\
\text { (Malvaceae) }\end{array}$ & “Menekong” in Babungo (Cameroon). & $\begin{array}{l}\text { Species native in America and now widely cultivated } \\
\text { in all tropical countries. }\end{array}$ & Leaves \\
\hline \multirow[t]{12}{*}{ Dystocia } & $\begin{array}{l}\text { Aloe buettneri } \\
\text { (Liliaceae) }\end{array}$ & $\begin{array}{l}\text { "Lapapegue" in Badenkop, “Kagbayi” in } \\
\text { Bamoun, "Lah-Ndih" in Bana, and "Adjan } \\
\text { nkom" in Eton (Cameroon). }\end{array}$ & $\begin{array}{l}\text { Savanna species, growing preferably in rocky areas. } \\
\text { Found from Mali to the Central Africa Republic, Con- } \\
\text { go, Angola, and Malawi. }\end{array}$ & $\begin{array}{l}\text { Whole } \\
\text { plant }\end{array}$ \\
\hline & $\begin{array}{l}\text { Aloevera } \\
\text { (Liliaceae) }\end{array}$ & $\begin{array}{l}\text { "Kouovut" or "Nchahsoure" in Bamoun } \\
\text { (Cameroon). }\end{array}$ & $\begin{array}{l}\text { Probably native of the Mediterranean region; } \\
\text { propagated by rhizome. }\end{array}$ & $\begin{array}{l}\text { Whole } \\
\text { plant }\end{array}$ \\
\hline & $\begin{array}{l}\text { Ampelocissus bombysiana } \\
\text { (Vitaceae) }\end{array}$ & "Apoumigea" in Mankon (Cameroon). & $\begin{array}{l}\text { African species of the Sudano-Guinean region, } \\
\text { found from Guinea to Congo. }\end{array}$ & Leaves \\
\hline & $\begin{array}{l}\text { Annona senegalensis } \\
\text { (Annonaceae) }\end{array}$ & “Saske” in Fufulde (Cameroon). & $\begin{array}{l}\text { Savanna plant recorded from Senegal to Nigeria. } \\
\text { Found also in the Central African Republic, Sudan, } \\
\text { and Cape Verde. }\end{array}$ & Leaves \\
\hline & $\begin{array}{l}\text { Basella alba } \\
\text { (Basellaceae) }\end{array}$ & $\begin{array}{l}\text { "Ndore" in Bafut, "Potouye" in Fufulde, and } \\
\text { "Loh" in Bagante (Cameroon). }\end{array}$ & West Africa to Asia, West Indies and East Africa. & $\begin{array}{l}\text { Leaves and } \\
\text { stems }\end{array}$ \\
\hline & $\begin{array}{l}\text { Buchholzia coriacea } \\
\text { (Capparaceae) }\end{array}$ & "Ngale" in Bassa (Cameroon). & $\begin{array}{l}\text { Humid, dense forest species, growing in the under- } \\
\text { growth, found from Guinea to Congo. }\end{array}$ & Leaves \\
\hline & $\begin{array}{l}\text { Cissus quadrangularis } \\
\text { (Vitaceae) }\end{array}$ & $\begin{array}{l}\text { "Coeur" in Bafut, "Ndieh gap” in Bamoun, } \\
\text { "Nkohsat" in Bagante, "Sango-di” in Bang- } \\
\text { wan, and "Njel” in Bassa (Cameroon). }\end{array}$ & $\begin{array}{l}\text { Widespread in the drier parts of Africa, Arabia, and } \\
\text { India. }\end{array}$ & Leafy stem \\
\hline & $\begin{array}{l}\text { Hibiscus rosa-sinensis } \\
\text { (Malvaceae) }\end{array}$ & None. & $\begin{array}{l}\text { Native to tropical Asia, the hibiscus is widely } \\
\text { cultivated in all tropical regions of the world as } \\
\text { ornamentals. }\end{array}$ & Leaves \\
\hline & $\begin{array}{l}\text { Momordica foetida } \\
\text { (Cucurbitaceae) }\end{array}$ & $\begin{array}{l}\text { "Nyako" in Bassa and "Engokom" or "Oyale } \\
\text { zom" in Bulu (Cameroon). }\end{array}$ & $\begin{array}{l}\text { Forest edges and clearings; margins of swamp and } \\
\text { riverine forests and of secondary thickets, also a } \\
\text { weed and colonizer of disturbed ground and of old } \\
\text { cultivations. Widely distributed in tropical Africa and } \\
\text { in South Africa. }\end{array}$ & Leafy twig \\
\hline & $\begin{array}{l}\text { Piptadeniastrum africanum } \\
\text { (Leguminoseae-Mimosoi- } \\
\text { deae) }\end{array}$ & $\begin{array}{l}\text { "Atui" in Beti and Fang, "Tombou" in Kaka, } \\
\text { and "Mpie" in Maka (Cameroon). }\end{array}$ & $\begin{array}{l}\text { Tree found in dense, humid forests. Found in } \\
\text { Cameroon, Sierra Leone, Angola, and Uganda. }\end{array}$ & Stem bark \\
\hline & $\begin{array}{l}\text { Terminalia glaucescens } \\
\text { (Combretaceae) }\end{array}$ & “Ogalu” in Sanaga (Cameroon). & $\begin{array}{l}\text { Savanna tree. Widespread from Guinea, Cameroon, } \\
\text { and Sudan. }\end{array}$ & Stem bark \\
\hline & $\begin{array}{l}\text { Vernonia guineensis } \\
\text { (Asteraceae) }\end{array}$ & $\begin{array}{l}\text { "Ibilihi" in Fufulde and "Shiji shokum" or } \\
\text { "Whislishuch" in Lamson (Cameroon). }\end{array}$ & $\begin{array}{l}\text { Widespread from Mali to Nigeria and spreading to } \\
\text { the Sudan. }\end{array}$ & $\begin{array}{l}\text { Fresh } \\
\text { leaves }\end{array}$ \\
\hline $\begin{array}{l}\text { Fetal } \\
\text { malposition }\end{array}$ & $\begin{array}{l}\text { Senecio biafrae } \\
\text { (Asteraceae) }\end{array}$ & $\begin{array}{l}\text { "Nsob" in Bakossi, "Nduwane" in Bana, and } \\
\text { "Nboh" in Lamso (Cameroon). }\end{array}$ & Cocoa plantation, fallows, roadsides. & Tops \\
\hline $\begin{array}{l}\text { Fetal mal- } \\
\text { presentation }\end{array}$ & $\begin{array}{l}\text { Piper umbellatum } \\
\text { (Piperaceae) }\end{array}$ & $\begin{array}{l}\text { "Mbubua" in Bana, "Mbebueh" in Band- } \\
\text { joun, "Me bout" in Bagangte, "Mbobou" in } \\
\text { Baleing, and "Aboo medjan" in Ewondo and } \\
\text { Bulu (Cameroon). }\end{array}$ & $\begin{array}{l}\text { Heliophile species, widespread from Guinea to } \\
\text { Cameroon and Angola. }\end{array}$ & Leaves \\
\hline
\end{tabular}


Table 2 Continued

\begin{tabular}{|c|c|c|c|c|}
\hline Disorders & Botanical name & Vernacular name & Origin & Part used \\
\hline \multirow{2}{*}{$\begin{array}{l}\text { Intrauterine } \\
\text { death/ } \\
\text { retained } \\
\text { dead fetus }\end{array}$} & $\begin{array}{l}\text { Abrus precatorius } \\
\text { (Leguminoseae- } \\
\text { Papilionoideae) }\end{array}$ & $\begin{array}{l}\text { "Nzo-zunang" in Babesi, “Suka” in Bassa, } \\
\text { "Nkwelnutie" in Bassa, and "Bellerni” in } \\
\text { Fufulde (Cameroon). }\end{array}$ & $\begin{array}{l}\text { Species of secondary formations of forest regions } \\
\text { extended into savanna. It grows in all intertropical } \\
\text { Africa and also in other parts of the tropical world. }\end{array}$ & Leaves \\
\hline & $\begin{array}{l}\text { Terminalia glaucenscens } \\
\text { (Combretaceae) }\end{array}$ & "Ogalu" in Sanaga (Cameroon). & $\begin{array}{l}\text { Savanna tree. Widespread from Guinea, Cameroon, } \\
\text { and Sudan. }\end{array}$ & Stem bark \\
\hline \multirow[t]{3}{*}{$\begin{array}{l}\text { Lactation } \\
\text { failure }\end{array}$} & $\begin{array}{l}\text { Commelina benghalensis } \\
\text { (Commelinaceae) }\end{array}$ & $\begin{array}{l}\text { "Nkwa" in Bafut, "Ngungwet" in Bamoun, } \\
\text { and "Kaalep" in Bassa (Cameroon). }\end{array}$ & $\begin{array}{l}\text { A weedy plant of open cultivated and wasted } \\
\text { ground, also in savanna. }\end{array}$ & Leafy twig \\
\hline & $\begin{array}{l}\text { Crinum zeylaninum } \\
\text { (Amaryllidaceae) }\end{array}$ & $\begin{array}{l}\text { "Laansi" in Bana, "Black mbongie" in } \\
\text { Banen, "Lilan li ngond" in Bassa, and "Ga- } \\
\text { dal-salma" in Fufulde (Cameroon). }\end{array}$ & $\begin{array}{l}\text { Savanna species growing in humid stations. It is } \\
\text { widespread in all intertropical Africa. }\end{array}$ & Bulb \\
\hline & $\begin{array}{l}\text { Guiera senegalensis } \\
\text { (Combretaceae) }\end{array}$ & $\begin{array}{l}\text { "Gelude" or "Guelogi" in Fufulde } \\
\text { (Cameroon). }\end{array}$ & $\begin{array}{l}\text { Sudano-sahelian species, widespread from Senegal } \\
\text { to Sudan, abundant in the fallow lands on sandy } \\
\text { soils. }\end{array}$ & Leaves \\
\hline \multirow[t]{2}{*}{$\begin{array}{l}\text { Placenta } \\
\text { retention }\end{array}$} & Bidens pilosa (Asteraceae) & $\begin{array}{l}\text { "Atchiti" in Bulu, "Njim njim" in Bassa, } \\
\text { and "Fouwan" or "Yiere" in Bamoun } \\
\text { (Cameroon). }\end{array}$ & Widespread in Cameroon. & Leafy twig \\
\hline & $\begin{array}{l}\text { Tetrapleura tetraptera } \\
\text { (Leguminoseae- } \\
\text { Mimosoideae) }\end{array}$ & $\begin{array}{l}\text { "Telele" in Badjoue and “Djetk” or “Essissa” } \\
\text { in Ewondo (Cameroon). }\end{array}$ & $\begin{array}{l}\text { Guinea-Congolese species, widespread over all in- } \\
\text { tertropical Africa, growing mostly in secondary for- } \\
\text { mations. }\end{array}$ & Root tuber \\
\hline \multirow[t]{9}{*}{$\begin{array}{l}\text { Poly- } \\
\text { hydramnios }\end{array}$} & $\begin{array}{l}\text { Ageratum conyzoides } \\
\text { (Asteraceae) }\end{array}$ & $\begin{array}{l}\text { "Eshing" in Akono, "Mobangtu" in Bali, } \\
\text { "Mejottefu" in Bamoun, "Ogaate" or "Ok- } \\
\text { pati" in Bulu, "Nyat elok" or "Okpati" in } \\
\text { Ewondo, and "Nde das se" in Sanaga } \\
\text { (Cameroon). }\end{array}$ & Widespread in Africa. & $\begin{array}{l}\text { Whole } \\
\text { plant }\end{array}$ \\
\hline & $\begin{array}{l}\text { Cleome rutidosperma } \\
\text { (Capparaceae) }\end{array}$ & $\begin{array}{l}\text { "Amborrenja" in Bafut, "Macomagniaga" } \\
\text { in Bassa, "Mephomonze" in Bouda, and } \\
\text { "Mbango" in Douala (Cameroon). }\end{array}$ & Species growing in all of tropical Africa. & $\begin{array}{l}\text { Whole } \\
\text { plant }\end{array}$ \\
\hline & $\begin{array}{l}\text { Commelina benghalensis } \\
\text { (Commelinaceae) }\end{array}$ & $\begin{array}{l}\text { "Nkwa" in Bafut, "Ngungwet" in Bamoun, } \\
\text { and "Kaalep" in Bassa (Cameroon). }\end{array}$ & $\begin{array}{l}\text { A weedy plant of open cultivated and wasted } \\
\text { ground, also in savanna. }\end{array}$ & $\begin{array}{l}\text { Whole } \\
\text { plant }\end{array}$ \\
\hline & $\begin{array}{l}\text { Eleusine indica } \\
\text { (Poaceae) }\end{array}$ & $\begin{array}{l}\text { "Lisingesinge" in Bakweri, "Ngongui" in } \\
\text { Bassa, and "Ngongui" in Douala (Camer- } \\
\text { oon). }\end{array}$ & $\begin{array}{l}\text { Species spread in all tropical regions; widespread in } \\
\text { all regions of tropical Africa. }\end{array}$ & $\begin{array}{l}\text { Flowering } \\
\text { plant }\end{array}$ \\
\hline & $\begin{array}{l}\text { Euphorbia hirta } \\
\text { (Euphorbiaceae) }\end{array}$ & $\begin{array}{l}\text { "Okoul bifes" in Ewondo, "Mpemeu" in } \\
\text { Bamoun, "Ewuda manyongo" in Douala, } \\
\text { and "Endemhi" in Fufulde (Cameroon). }\end{array}$ & $\begin{array}{l}\text { Wild species, growing in various areas, along roads, } \\
\text { particularly on waste grounds and in old cultivation. }\end{array}$ & $\begin{array}{l}\text { Whole } \\
\text { plant }\end{array}$ \\
\hline & $\begin{array}{l}\text { Portulaca oleracea } \\
\text { (Portulacaceae) }\end{array}$ & $\begin{array}{l}\text { "Kepingoup" or "Koupugoup” in Bamoun, } \\
\text { "Derdegue" in Mvele, and “Nyukutu nyu- } \\
\text { kutu" in Douala (Cameroon). }\end{array}$ & Cosmopolitan and ruderal species. & $\begin{array}{l}\text { Whole } \\
\text { plant }\end{array}$ \\
\hline & $\begin{array}{l}\text { Triplotaxis stellulifera } \\
\text { (Asteraceae) }\end{array}$ & $\begin{array}{l}\text { "Mudike musadi" in Douala, "Ntsam } \\
\text { ntsam" in Ewondo, and "Jogue" in Maka } \\
\text { (Cameroon). }\end{array}$ & $\begin{array}{l}\text { Weed widespread in the clearings of forest regions } \\
\text { from Liberia to Gabon and in Uganda. }\end{array}$ & $\begin{array}{l}\text { Whole } \\
\text { plant }\end{array}$ \\
\hline & $\begin{array}{l}\text { Gossypium barbadense } \\
\text { (Malvaceae) }\end{array}$ & “Menekong" in Babungo (Cameroon). & $\begin{array}{l}\text { Species native in America and now widely cultivated } \\
\text { in all tropical countries. }\end{array}$ & Leaves \\
\hline & $\begin{array}{l}\text { Hibiscus surattensis } \\
\text { (Malvaceae) }\end{array}$ & $\begin{array}{l}\text { "Molong" or "Chwenanton" in Bouda } \\
\text { (Cameroon). }\end{array}$ & $\begin{array}{l}\text { Widespread in the topics of the old world; from } \\
\text { Senegal to East Africa. }\end{array}$ & Tops \\
\hline \multirow[t]{4}{*}{$\begin{array}{l}\text { Postpartum } \\
\text { hemorrage }\end{array}$} & $\begin{array}{l}\text { Cogniauxia podolaena } \\
\text { (Cucurbitaceae) }\end{array}$ & $\begin{array}{l}\text { "Kol ekona ezouo" in Badjoun, "Fui gbain" } \\
\text { in Bali, "Kon-afu" in Banwa, and "Beyeme } \\
\text { elok" in Bulu (Cameroon) }\end{array}$ & $\begin{array}{l}\text { Species widespread in Gabon, Cameroon, and } \\
\text { Congo; found also in Angola. }\end{array}$ & Tuber \\
\hline & $\begin{array}{l}\text { Frenandoa adolfi-frederici } \\
\text { (Bignoniaceae) }\end{array}$ & "Ndjuewe" in Badjoue (Cameroon). & $\begin{array}{l}\text { Species widespread in Cameroon, Central African } \\
\text { Republic, Gabon, and Democratic Republic of } \\
\text { Congo. }\end{array}$ & Bark \\
\hline & $\begin{array}{l}\text { Heisteria zimmereri } \\
\text { (Olacaceae) }\end{array}$ & "Ebarekoul” in Badjoue (Cameroon). & $\begin{array}{l}\text { Widespread from Cameroon to Democratic } \\
\text { Republic of Congo. }\end{array}$ & Bark \\
\hline & $\begin{array}{l}\text { Tetrapleura tetraptera } \\
\text { (Leguminosae- } \\
\text { Mimosoideae) }\end{array}$ & $\begin{array}{l}\text { "Telele" in Badjoue and “Djetk” or “Essissa” } \\
\text { in Ewondo (Cameroon). }\end{array}$ & $\begin{array}{l}\text { Guinea-Congolese species, widespread over all of } \\
\text { intertropical Africa, growing mostly in secondary } \\
\text { formations. }\end{array}$ & Fruit \\
\hline Prenatal care & Basella alba (Basellaceae) & $\begin{array}{l}\text { "Ndore" in Bafut, "Potouye" in Fufulde, and } \\
\text { "Loh" in Bagangte (Cameroon). }\end{array}$ & West Africa to Asia, West Indies and East Africa. & $\begin{array}{l}\text { Whole } \\
\text { plant }\end{array}$ \\
\hline \multirow[t]{2}{*}{$\begin{array}{l}\text { Spurious } \\
\text { labor pains }\end{array}$} & $\begin{array}{l}\text { Emilia praetermissa } \\
\text { (Asteraceae) }\end{array}$ & "Etukelehe” in Noni (Cameroon). & $\begin{array}{l}\text { Species frequently found in the savanna and fallow } \\
\text { post-forests. }\end{array}$ & Aerial parts \\
\hline & $\begin{array}{l}\text { Eremomastax speciosa } \\
\text { (Acanthaceae) }\end{array}$ & $\begin{array}{l}\text { "Tankebi” in Mbo, "Purple leaf" in Pidgin, } \\
\text { “Essan dja” in Yebekolo, and “Ekunte” in } \\
\text { Bakossi (Cameroon). }\end{array}$ & Widespread in tropical Africa. & Aerial parts \\
\hline
\end{tabular}


Table 2 Continued

\begin{tabular}{|c|c|c|}
\hline Disorders & Botanical name & Vernacular name \\
\hline \multirow[t]{10}{*}{$\begin{array}{l}\text { Threatened } \\
\text { abortion }\end{array}$} & Bidens pilosa (Asteraceae) & $\begin{array}{l}\text { "Atchiti" in Bulu, "Njim njim" in Bassa, } \\
\text { and "Fouwan" or "Yiere" in Bamoun } \\
\text { (Cameroon). }\end{array}$ \\
\hline & $\begin{array}{l}\text { Borreria ocymoides } \\
\text { (Rubiaceae) }\end{array}$ & "Enore" in Ashon (Cameroon). \\
\hline & $\begin{array}{l}\text { Clerodendrum speciosissi- } \\
\text { mum (Verbenaceae) }\end{array}$ & $\begin{array}{l}\text { "Legkefen" in Babungo and "Dibielog" in } \\
\text { Ewondo (Cameroon). }\end{array}$ \\
\hline & $\begin{array}{l}\text { Justicia insularis } \\
\text { (Acanthaceae) }\end{array}$ & $\begin{array}{l}\text { "Lang" in Bakoko, "Esumejom" in Bakossi, } \\
\text { "Ngnwangmekop" in Bassa, and "Efi” in } \\
\text { Ejagem (Cameroon). }\end{array}$ \\
\hline & $\begin{array}{l}\text { Hibiscus sabdariffa } \\
\text { (Malvaceae) }\end{array}$ & $\begin{array}{l}\text { "Mejue” in Bakossi, "Fouchi” in Bamoun, } \\
\text { "Ewouda maya” in Douala, "Okro'o" in } \\
\text { Kwen, or "Essan" in Mvele (Cameroon). }\end{array}$ \\
\hline & $\begin{array}{l}\text { Mammea africana } \\
\text { (Clusiaceae) }\end{array}$ & $\begin{array}{l}\text { "Houng abodzog" in Bassa and "Abot zok" } \\
\text { or "Houng abodzog" in Ewondo (Camer- } \\
\text { oon). }\end{array}$ \\
\hline & $\begin{array}{l}\text { Nauclea pobeguinii } \\
\text { (Rubiaceae) }\end{array}$ & "Banochi” in Hausa (Cameroon). \\
\hline & $\begin{array}{l}\text { Peperomia pellucida } \\
\text { (Piperaceae) }\end{array}$ & $\begin{array}{l}\text { "Eborbo" in Bakossi, "Njel" in Bassa, "Ido- } \\
\text { kamokwe" in Bakweri, and "Ewonda doret" } \\
\text { in Douala (Cameroon). }\end{array}$ \\
\hline & $\begin{array}{l}\text { Piper guineense } \\
\text { (Piperaceae) }\end{array}$ & "Enore" in Ashon (Cameroon). \\
\hline & $\begin{array}{l}\text { Vernonia ampla } \\
\text { (Asteraceae) }\end{array}$ & $\begin{array}{l}\text { "Mako" in Bandjoun, "Merke" in Bana, } \\
\text { "Shiji" in Lamso (Cameroon). }\end{array}$ \\
\hline
\end{tabular}

\begin{tabular}{|c|c|}
\hline Origin & Part used \\
\hline Widespread in Cameroon. & Leaves \\
\hline Frequent in secondary bush. Tropical Africa. & $\begin{array}{l}\text { Whole } \\
\text { plant }\end{array}$ \\
\hline Introduced ornamental plant with no precise habitat & $\begin{array}{l}\text { Fresh } \\
\text { leaves }\end{array}$ \\
\hline $\begin{array}{l}\text { Ruderal species. Widespread elsewhere through in- } \\
\text { tertropical Africa. }\end{array}$ & $\begin{array}{l}\text { Whole } \\
\text { plant }\end{array}$ \\
\hline Widely cultivated in the tropics. & $\begin{array}{l}\text { Leaves and } \\
\text { stems }\end{array}$ \\
\hline $\begin{array}{l}\text { Species found in the forest. Distributed from Sierra } \\
\text { Leone to Uganda and Angola. }\end{array}$ & Stem bark \\
\hline $\begin{array}{l}\text { Fringing forest species, growing mainly in forest re- } \\
\text { gions. Extending from Senegal to Nigeria, } \\
\text { Cameroon, and Zimbabwe. }\end{array}$ & Bark \\
\hline $\begin{array}{l}\text { Pantropical species, ruderal, occurring especially } \\
\text { around dwelling locations. }\end{array}$ & $\begin{array}{l}\text { Whole } \\
\text { plant }\end{array}$ \\
\hline $\begin{array}{l}\text { Humid dense forest species, dispersed from Guinea } \\
\text { to Uganda. }\end{array}$ & Fruits \\
\hline $\begin{array}{l}\text { Found in clearings of upland forests; rare species, } \\
\text { recorded only from Guinea and Sierra Leone. }\end{array}$ & Shoots \\
\hline
\end{tabular}

\section{References}

1 Bussmann RW. Ethnobotany of the Samburu of Mt. Nyiru, South Turkana, Kenya. J Ethnobiol Ethnomed 2006, advance online publication; DOI: $10.1186 / 1746-4269-2-35$

2 Okoli RI, Aigbe O, Ohaju-Obodo JO, Mensah JK. Medicinal plants used for managing some common ailments among Esan People of Edo State, Nigeria. Pakistan J Nutr 2007; 6: 490-496

3 WHO. WHO calls on African governments to formally recognize traditional medicine. 31 August 2003, Johannesburg, South Africa. Geneva: WHO; 2003

4 Williamson EM, Okpako DT, Evans FJ. Pharmacological methods in phytotherapy reaserch, Vol. 1: Selection preparation and pharmacological evaluation of plant material. London: John Wiley and Sons Ltd.; 1996: $191-212$

5 Malan DF, Neuba DF. Traditional practices and medicinal plants use during pregnancy by Anyi-Ndenye women (Eastern Côte d'Ivoire). Afr J Reprod Health 2011; 15: 85-93

6 Andersen GD. Phytoestrogens: what they are and how they work. Dyn Chiropract 2000; 18: 21

7 Sonnenschein C, Soto AM. An updated review of environmental estrogen and androgen mimics and antagonists. J Steroid Biochem Mol Biol 1998; 65: 143-150

8 Whitten PL, Lewis C, Russel E. Potential adverse effects of phytoestrogènes. J Nutr 1995; 125: 771S-776S

9 Cos P, De Bruyne T, Apers S, Vanden Berghe D, Pieters L, Vlietinck AJ. Phytoestrogens: recent developments. Planta Med 2003; 69: 589-599

10 Tanee FSF, Njamen D, Magne Ndé C, Wanji J, Zierau O, Fomum ZT, Vollmer $G$. Estrogenic effects of the ethyl-acetate extract of the stem bark of Erythrina lysistemon Hutch (Fabaceae). Phytomedicine 2007; 14: 222226

11 Njamen D, Magne Ndé CB, Tanee FZ, Mbanya JC. Preventive effects of an extract of Erythrina lysistemon (Fabaceae) on some menopausal problems: studies on the rat. J Complement Integr Med 2007; 4: 1-17

12 Magne Ndé C, Njamen D, Mbanya CL, Zierau O, Vollmer G, Tanee Fomum Z. Estrogenic effects of a methanol extract of the fruit of Brenania brieyi de Wild (Rubiaceae). J Nat Med 2007; 61: 86-89

13 Njamen D, Magne Ndé CB, Tanee Fomum Z, Vollmer G. Effects of the extracts of some tropical medicinal plants on estrogen inducible yeast and Ishikawa screens, and on ovariectomized rats. Pharmazie 2008; 63: $164-168$

14 Djiogue S, Halabalaki M, Alexi X, Njamen D, Tanee Fomum Z, Alexis MN, Skaltsounis A. Isoflavonoids from Erythrina poeppigiana: evaluation of their binding affinity for the estrogen receptor. J Nat Prod 2009; 72: 1603-1607

15 Djiogue S, Njamen D, Halabalaki M, Kretzschmar G, Beyer A, Mbanya JC, Skaltsounis AL, Vollmer G. Estrogenic properties of naturally occurring prenylated isoflavones in U2OS human osteosarcoma cells: Structureactivity relationships. J Steroid Biochem Mol Biol 2010; 120: 184-191

16 Telefo PB, Moundipa PF, Tchana AN, Tchounaguep Dzickote C, Mbiapo FT. Effects of an aqueous extract of Aloe buettneri, Justicia insularis, Hisbiscus macranthus, Dicliptera verticillata on some physiological and biochemical parameters of reproduction in immature female rats. J Ethnopharmacol 1998; 63: 193-200

17 Telefo PB, Moundipa PF, Tchouanguep FM. Oestrogenicity and effect on hepatic metabolism of the aqueous extract of the leaf mixture of Aloe buettneri, Dicliptera verticillata, Hisbiscus macranthus, Justicia insularis. Fitoterapia 2002; 73: 472-478

18 Lienou LL, Telefo PB, Bale B, Yemele D, Tagne RS, Goka SC, Lemfack CM, Mouokeu C, Moundipa P. Effect of the aqueous extract of Senecio biafrae (Oliv. \& Hiern) J. Moore on sexual maturation of immature female rat. BMC Complement Alternat Med 2012; 12: 36

19 Mvondo MA, Njamen D, Tanee Fomum S, Wandji J, Vollmer G. A postmenopause-like model of ovariectomized Wistar rats to identify active principles of Erythrina lysistemon (Fabaceae). Fitoterapia 2011; 82: 939-949

20 Mvondo MA, Njamen D, Tanee Fomum S, Wandji J. Effects of alpinumisoflavone and abyssinoneV-4'-methyl ether derived from Erythrina lysistemon (Fabaceae) on the genital tract of ovariectomized female Wistar rat. Phytother Res 2012; 26: 1029-1036

21 Ketcha Wanda GJM, Njamen D, Yankep E, Tagatsing Fotsing M, Tanee Fomum Z, Wober J. Estrogenic properties of isoflavones derived from Millettia griffoniana. Phytomedicine 2006; 13: 139-145

22 Ketcha Wanda GJM, Kretzschmar G, Njamen D, Tagatsing Fotsing M, Yankep E, Vollmer G. Modulation of some estrogen-responsive genes in the vena cava of ovariectomised Wistar rats by griffonianone C, an isoflavone derived from Millettia griffoniana Baill. (Fabaceae). Fitoterapia 2010; 81: 1232-1238 
23 Ketcha Wanda GJM, Starcke S, Zierau O, Njamen D, Richter T, Vollmer G. Estrogenic activity of griffonianone $\mathrm{C}$, an isoflavone from the root bark of Millettia griffoniana: regulation of the expression of estrogen responsive genes in uterus and liver of ovariectomized rats. Planta Med 2007; 73: 1-7

24 Dixit P, Chand K, Khan MP, Siddiqui JA, Tewari D, Ngueguim FT, Chattopadhyay N, Maurya R. Phytoceramides and acylated phytosterol glucosides from Pterospermum acerifolium Willd. seed coat and their osteogenic activity. Phytochemistry 2012; 81: 117-125

25 Ritchie HE. The safety of herbal medicine use during pregnancy. Front Fetal Health 2001; 3: 259-266

26 Chacko MR, McGill L, Johnson TC, Smith PB, Nenney SW. Vaginal douching in teenagers attending a family planning clinic. J Adolesc Health Care 1989; 10: 217-219

27 Brown RC, Brown JE, Ayowa OB. Vaginal inflammation in Africa. N Engl J Med 1992; 327: 572

28 Irwin K, Mibandumba N, Mbuyi K, Ryder R, Sequeira D. More on vaginal inflammation in Africa [letter]. N Engl J Med 1993; 328: 888-889

29 US Census Bureau. World POPClock Projection. Available at http:// www.census.gov/main/www/popclock.html. Accessed April 17, 2005.

30 Henshaw SK. Unintended pregnancy in the United States. Fam Plann Perspect 1998; 30: 24-29

31 Grow DR, Ahmed S. New contraceptive methods. Obstet Gynecol Clin North Am 2000; 27: 901-916

32 Abu Adakole H, Uchendu Chukwuka N. Antifertility activity of aqueous ethanolic extract of Hymenocardia acida stem bark in female rats. Iranian J Reprod Med 2011; 9: 217-222
33 Sathyaraj A, Basaveswara Rao MV, Satyanarayana V. Gradient RP-HPLC method for the determination of purity and assay of raloxifene hydrochloride in bulk drug. Recent trends in pharmaceutical chemistry for drug discovery. IJRPC 2011; 1: 372-378

34 Emslie C, Grimshaw J, Templeton A. Do clinical guidelines improve general practice management and referral of infertile couples? Br Med J 1993; 306: 1728-1731

35 Bhatti LI, Fikree FF, Khan A. The quest of infertile women in squatter settlements of Karachi, Pakistan: a qualitative study. Soc Sci Med 1999; 49: 637-649

36 Leke RII, Oduma JA, Bassol-Mayageitia S, Bacha AM, Grior KM. Regional and geographical variations in infertility: effects of environmental, cultural and socioeconomic factors. Environ Health Perspect 1993; 101 (Suppl. 2): 73-80

37 Alemnji GA, Thomas KD. Socio-biological status of Nigerian males with primary and secondary infertility. East Afr Med J 1997; 74: 519-522

38 Gerrits T. Social and cultural aspects of infertility in Mozambique. Patient Educ Couns 1997; 31: 39-48

39 Sundby J. Infertility in the Gambia: traditional and modern health care. Patient Educ Couns 1997; 31: 29-37

40 Adjanohoun JE, Aboubakar N, Dramane K, Ebot ME, Ekpere JA, Enow-Orock EG, Focho D, Gbile ZO, Kamanyi A, Kamsu Kom J, Keita A, Mbenkum T, Mbi CN, Mbiele AL, Mbome IL, Mubiru NK, Nancey WL, Nkongmeneck B, Satabie B, Sofowora A, Tamze V, Wirmum CK. Traditional medicine and pharmacopoeia: contribution to ethnobotanical and floristic studies in Cameroon. Porto-Novo, Benin: OAU/STRC Publishing House; 1996: 12607 